Prepared in cooperation with the Illinois Department of Natural Resources and the National Weather Service

\title{
Development and Evaluation of a Reservoir Model for the Chain of Lakes in Illinois
}

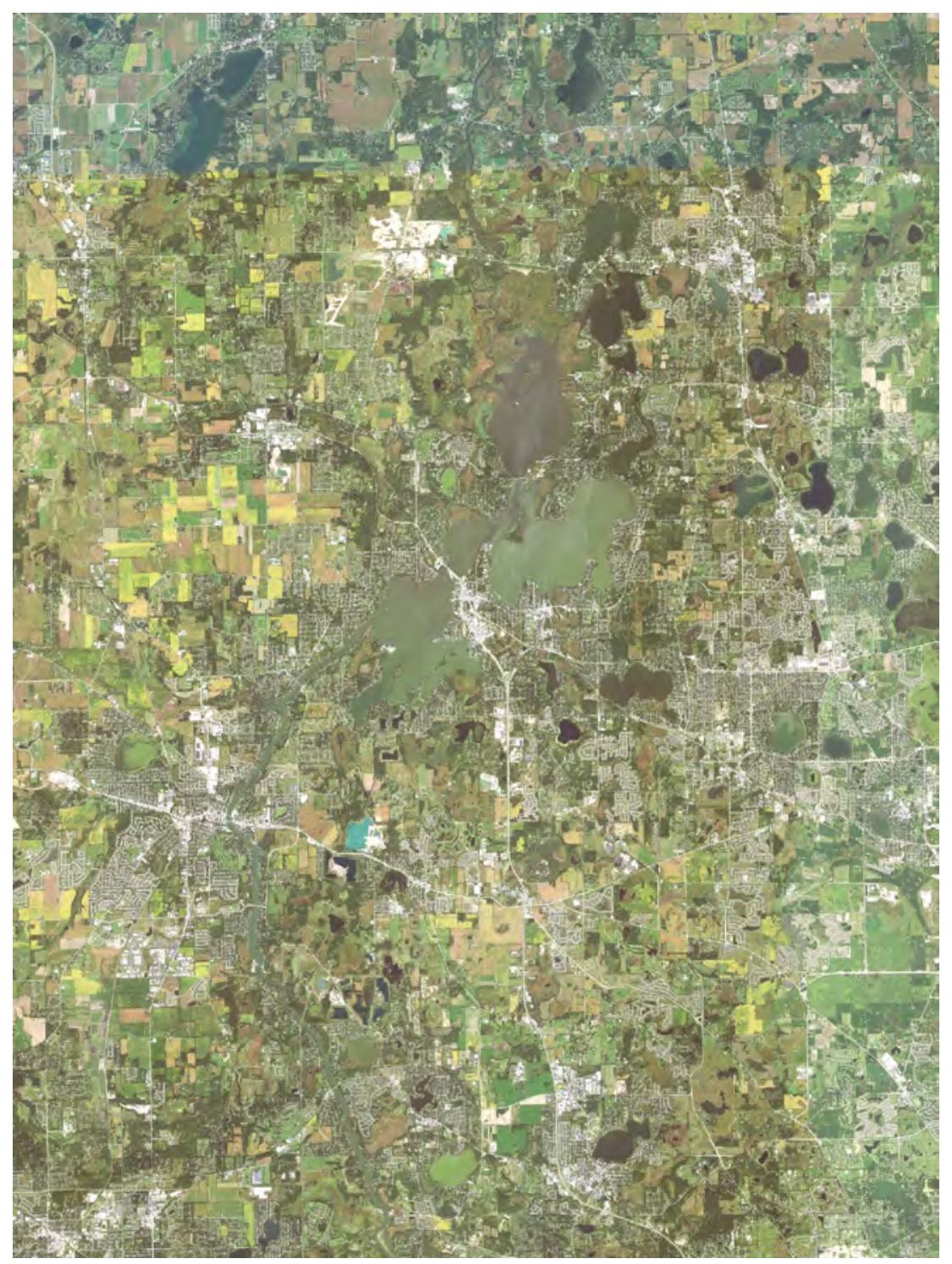

Scientific Investigations Report 2016-5155 
Cover. Areal image of the region surrounding the Chain of Lakes reservoir system in northeastern Illinois. Image from U.S. Department of Agriculture, Farm Service Agency National Agriculture Imagery Program (NAIP), Illinois and Wisconsin, 2015. 


\section{Development and Evaluation of a Reservoir Model for the Chain of Lakes in Illinois}

By Marian M. Domanski

Prepared in cooperation with the

Illinois Department of Natural Resources and the National Weather Service

Scientific Investigations Report 2016-5155 


\section{U.S. Department of the Interior SALLY JEWELL, Secretary}

\section{U.S. Geological Survey Suzette M. Kimball, Director}

\section{U.S. Geological Survey, Reston, Virginia: 2017}

For more information on the USGS - the Federal source for science about the Earth, its natural and living resources, natural hazards, and the environment-visit http://www.usgs.gov or call 1-888-ASK-USGS.

For an overview of USGS information products, including maps, imagery, and publications, visit http://store.usgs.gov.

Any use of trade, firm, or product names is for descriptive purposes only and does not imply endorsement by the U.S. Government.

Although this information product, for the most part, is in the public domain, it also may contain copyrighted materials as noted in the text. Permission to reproduce copyrighted items must be secured from the copyright owner.

Suggested citation:

Domanski, M.M., 2017, Development and evaluation of a reservoir model for the Chain of Lakes in Illinois: U.S. Geological Survey Scientific Investigations Report 2016-5155, 21 p., https://doi.org/10.3133/sir20165155.

ISSN 2328-0328 (online) 


\section{Acknowledgments}

Rick Gosch, Rita Lee, and Brad Winters (Illinois Department of Natural Resources-Office of Water Resources) supported the use of advanced methodologies in this study. Technical assistance was provided by Brian Connelly and Justin Palmer (National Weather Service). Jennifer Sharpe (U.S. Geological Survey) provided report illustration development. Technical reviews of the report were provided by Rodney Southard (U.S. Geological Survey) and Justin Palmer (National Weather Service). 



\section{Contents}

Acknowledgments ...................................................................................................................ii

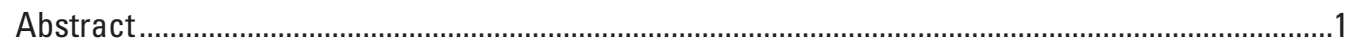

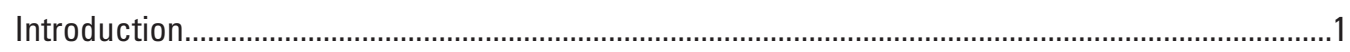

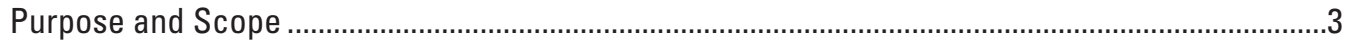

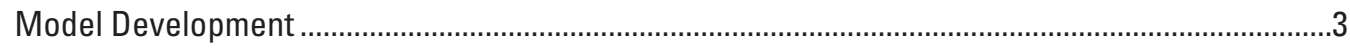

Physical Component Definitions ................................................................................................

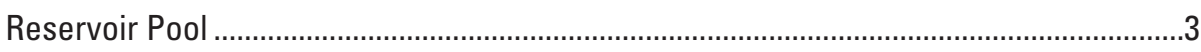

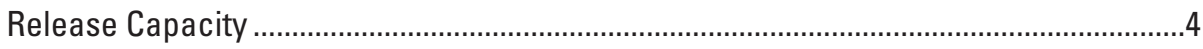

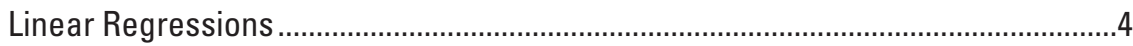

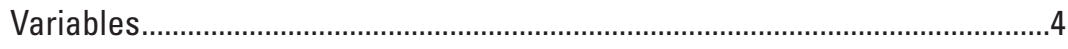

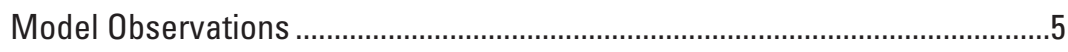

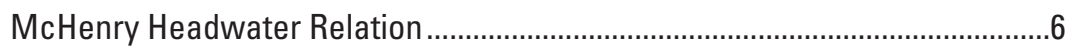

McHenry Tailwater Relation .............................................................................

Estimating Water-Surface Elevations...................................................................

Control Structure Ratings ...............................................................................

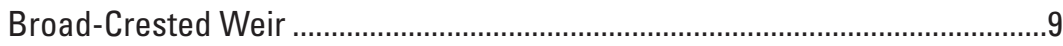

Hinged-Crest Gate .....................................................................................

Sluice Gates ................................................................................................

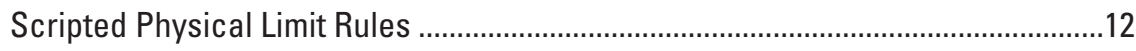

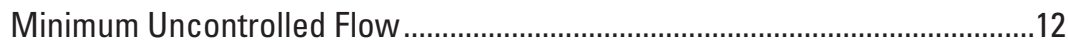

Minimum Flow from Minimum Fall ..................................................................13

Maximum Controlled and Uncontrolled Flow...................................................13

Maximum Flow from Maximum Fall ................................................................13

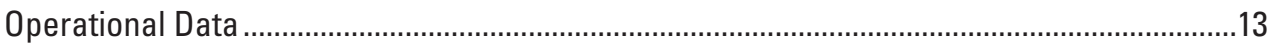

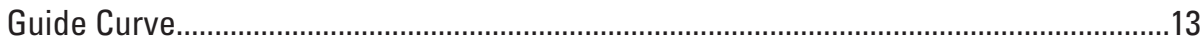

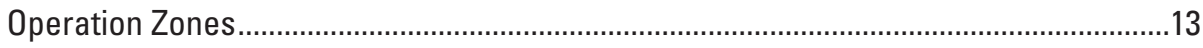

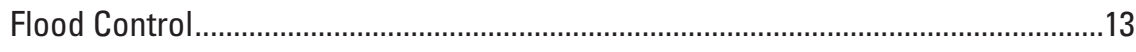

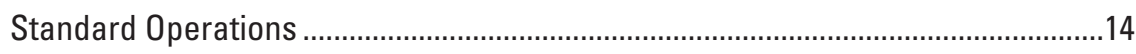

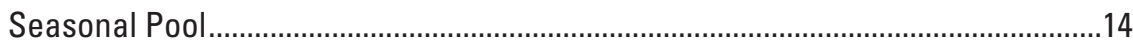

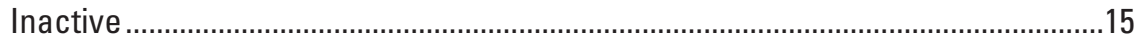

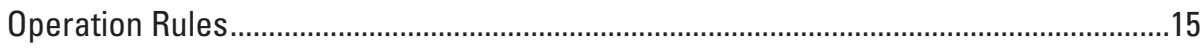

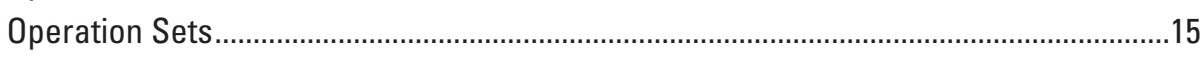

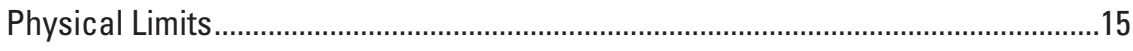

Standard Operations ...........................................................................................15

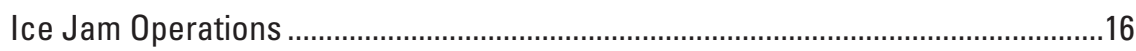

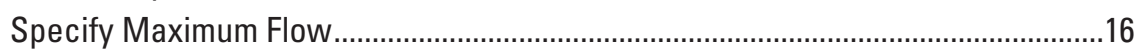

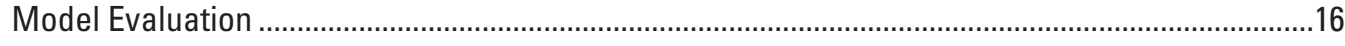

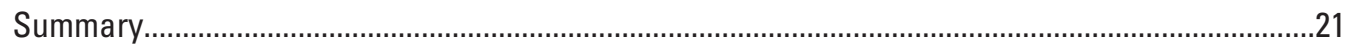

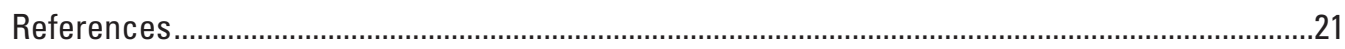




\section{Figures}

1. Map showing real-time streamgage stations in and near the Chain of Lakes on the Fox River in northeastern Illinois.

2. Graph showing storage-elevation curve for the Chain of Lakes reservoir on the Fox River in northeastern Illinois.

3. Graphs showing complex relation between $A$, reservoir pool elevation at Fox Lake near Lake Villa, Illinois, and water-surface elevation at Fox River near McHenry, III., and $B$, flow at Fox River near McHenry, Ill., and Fox River near Johnsburg, III., and water-surface elevation at Fox River near McHenry, III.

4. Diagram showing the relation between the gage height and fall variables used in the linear regression models for the outlet of the Chain of Lakes reservoir on the Fox River in northeastern Illinois....

5. Graphs showing distributional and seasonal characteristics of the real-time variables used in the development of the linear regression models for the Chain of Lake reservoir on the Fox River in northeastern Illinois.

6. Graphs showing measured and computed $A$, flow, $B$, gage height at Fox River near McHenry, Illinois, and $C$, water-surface elevation fall between Fox Lake near Lake Villa, III., and Fox River near McHenry, III.

7. Scatter plot of flow-gage height model for observations at Fox River (tailwater) near McHenry, Illinois

8. Graphs showing computed and measured flow and gage height at Fox River (tailwater) near McHenry, Illinois

9. Graph showing elevations of operation zones used in the Chain of Lakes reservoir model

10. Graph showing simulated and observed elevation time series at Fox Lake near Lake Villa, Illinois, plotted for the event that has an observed peak pool elevation of $739.46 \mathrm{ft}$ that occurs on May 28, 2004, at 12:00 p.m.

11. Graph showing simulated and observed elevation time series at Fox Lake near Lake Villa, Illinois, plotted for the event that has an observed peak pool elevation of $739.96 \mathrm{ft}$ that occurs on August 27, 2007, at 12:00 p.m. .

12. Graph showing simulated and observed elevation time series at Fox Lake near Lake Villa, Illinois, plotted for the event that has an observed peak pool elevation of $739.52 \mathrm{ft}$ that occurs on April 15, 2008, at 6:00 p.m.

13. Graph showing simulated and observed elevation time series at Fox Lake near Lake Villa, Illinois, plotted for the event that has an observed peak pool elevation of $740.15 \mathrm{ft}$ that occurs on June 18, 2008, at 6:00 p.m.

14. Graph showing simulated and observed elevation time series at Fox Lake near Lake Villa, Illinois, plotted for the event that has an observed peak pool elevation of $738.97 \mathrm{ft}$ that occurs on May 4, 2009, at 12:00 p.m.

15. Graph showing simulated and observed elevation time series at Fox Lake near Lake Villa, Illinois, plotted for the event that has an observed peak pool elevation of $738.58 \mathrm{ft}$ that occurs on June 23,2009 , at 12:00 p.m.

16. Graph showing simulated and observed elevation time series at Fox Lake near Lake Villa, Illinois, plotted for the event that has an observed peak pool elevation of $738.64 \mathrm{ft}$ that occurs on August 3, 2010, at 12:00 p.m.

17. Graph showing simulated and observed elevation time series at Fox Lake near Lake Villa, Illinois, plotted for the event that has an observed peak pool elevation of $740.90 \mathrm{ft}$ that occurs on April 22, 2013, at 6:00 p.m. 
18. Graph showing simulated and observed elevation time series at Fox Lake near Lake Villa, Illinois, plotted for the event that has an observed peak pool elevation of $738.81 \mathrm{ft}$ that occurs on July 1, 2013, at 12:00 p.m.

19. Scatter plot of simulated and observed peak elevations at Fox Lake near Lake Villa, Illinois.

\section{Tables}

1. Hydrologic stations near the Chain of Lakes on the Fox River in northeastern Illinois.

2. Description of variables used in the linear regression models for the outlet of the Chain of Lakes reservoir on the Fox River in northeastern Illinois.....

3. Observations used in the development of the linear regression models 7

4. Measured and computed observations of the variables for the gage height-flowfall model used at the Fox River near McHenry, Illinois, streamgage.....

5. Nash-Sutcliffe model efficiency coefficient calculated for the variables in the gage height-flow-fall used at the Fox River near McHenry, Illinois, streamgage ...........11

6. Measured and computed observations of the variables for the flow-gage height model used at the Fox River (tailwater) near McHenry, Illinois, streamgage

7. Nash-Sutcliffe model efficiency coefficient calculated for the variables in the flow-gage height model used at the Fox River near McHenry, Illinois, streamgage ......12

8. Physical limit rules in the Chain of Lakes Hydrologic Engineering Center-Reservoir System Simulation model

9. Operation rules in the Chain of Lakes Hydrologic Engineering Center-Reservoir

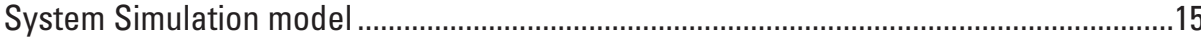

10. Summary of operation zones and rules applied in each operation set...........................16

11. Comparison of selected peak elevations at Fox Lake near Lake Villa, Illinois, from a simulated time series beginning October 1, 2003, and ending October 1, 2013

12. Nash-Sutcliffe model efficiency coefficient for the prediction of peak elevation at Fox Lake near Lake Villa, Illinois

\section{Conversion Factors}

U.S. customary units to International System of Units

\begin{tabular}{lcl}
\hline \multicolumn{1}{c}{ Multiply } & By & \multicolumn{1}{c}{ To obtain } \\
\hline foot $(\mathrm{ft})$ & Length & \\
mile $(\mathrm{mi})$ & 0.3048 & meter $(\mathrm{m})$ \\
& 1.609 & kilometer $(\mathrm{km})$ \\
\hline square mile $\left(\mathrm{mi}^{2}\right)$ & Area & \\
\hline & 2.590 & square kilometer $\left(\mathrm{km}^{2}\right)$ \\
\hline acre-foot $($ acre-ft) & Volume & \\
\hline & 1,233 & cubic meter $\left(\mathrm{m}^{3}\right)$ \\
\hline cubic foot per second $\left(\mathrm{ft}^{3} / \mathrm{s}\right)$ & Flow rate & \\
\hline
\end{tabular}




\section{Datum}

Vertical coordinate information is referenced to the National Geodetic Vertical Datum of 1929 (NGVD 29).

Elevation, as used in this report, refers to distance above the vertical datum.

\section{Abbreviations}

$\begin{array}{ll}\text { BCW } & \text { broad-crested weir } \\ \text { CHPS } & \text { Community Hydrologic Prediction System } \\ F & \text { fall } \\ G_{H W} & \text { headwater gage height at McHenry, III. } \\ \text { GMFR } & \text { geometric mean functional relationship } \\ \mathrm{G}_{\text {LV }} & \text { gage height near Lake Villa, III. } \\ \mathrm{G}_{\text {TW }} & \text { tailwater gage height at McHenry, III. } \\ \mathrm{h}_{1 B C W} & \text { broad-crested weir headwater height } \\ \mathrm{h}_{3 B C W} & \text { broad-crested weir tailwater height } \\ \mathrm{h}_{1 H C G} & \text { hinged-crest gate headwater height } \\ \mathrm{h}_{3 H C G} & \text { hinged-crest gate tailwater height } \\ \mathrm{h}_{1 S L} & \text { sluice gate headwater height } \\ \mathrm{h}_{3 S L} & \text { sluice gate tailwater height } \\ \mathrm{h}_{\mathrm{gSL}} & \text { sluice gate opening } \\ \text { HCG } & \text { hinged-crest gate } \\ \text { HEC-ResSIM } & \text { Hydrologic Engineering Center-Reservoir System Simulation } \\ \text { IDNR-OWR } & \text { Illinois Department of Natural Resources-0ffice of Water Resources } \\ \text { NWS } & \text { National Weather Service } \\ \mathrm{p}^{\text {HCG }} & \text { hinged-crest gate opening } \\ 0 & \text { flow } \\ \text { SL } & \text { sluice gate } \\ \text { USGS } & \text { U.S. Geological Survey } \\ \mathrm{Z}_{\text {HW }} & \text { headwater elevation } \\ \mathrm{Z}_{\text {LV }} & \text { reservoir pool elevation } \\ \mathrm{Z}_{\text {TW }} & \text { tailwater elevation } \\ & \end{array}$




\title{
Development and Evaluation of a Reservoir Model for the Chain of Lakes in Illinois
}

\author{
By Marian M. Domanski
}

\section{Abstract}

Forecasts of flows entering and leaving the Chain of Lakes reservoir on the Fox River in northeastern Illinois are critical information to water-resource managers who determine the optimal operation of the dam at McHenry, Illinois, to help minimize damages to property and loss of life because of flooding on the Fox River. In 2014, the U.S. Geological Survey; the Illinois Department of Natural Resources, Office of Water Resources; and National Weather Service, North Central River Forecast Center began a cooperative study to develop a system to enable engineers and planners to simulate and communicate flows and to prepare proactively for precipitation events in near real time in the upper Fox River watershed. The purpose of this report is to document the development and evaluation of the Chain of Lakes reservoir model developed in this study.

The reservoir model for the Chain of Lakes was developed using the Hydrologic Engineering Center-Reservoir System Simulation program. Because of the complex relation between the dam headwater and reservoir pool elevations, the reservoir model uses a linear regression model that relates dam headwater elevation to reservoir pool elevation. The linear regression model was developed using 17 U.S. Geological Survey streamflow measurements, along with the gage height in the reservoir pool and the gage height at the dam headwater. The Nash-Sutcliffe model efficiency coefficients for all three linear regression model variables ranged from 0.90 to 0.98 .

The reservoir model performance was evaluated by graphically comparing simulated and observed reservoir pool elevation time series during nine periods of high pool elevation. In addition, the peak elevations during these time periods were graphically compared to the closest-in-time observed pool elevation peak. The mean difference in the simulated and observed peak elevations was -0.03 feet, with a standard deviation of 0.19 feet. The Nash-Sutcliffe coefficient for peak prediction was calculated as 0.94 . Evaluation of the model based on accuracy of peak prediction and the ability to simulate an elevation time series showed the performance of the model was satisfactory.

\section{Introduction}

Flow forecasts entering and leaving the Chain of Lakes reservoir on the Fox River in northeastern Illinois are critical to the optimal operation of the dam at McHenry, Ill. (fig. 1), also referred to as Stratton Dam, according to the operational guidelines in use. The dam at McHenry is used primarily to maintain a pool for boating, fishing, and recreation in the Chain of Lakes; however, during flood events, the optimal operation of the dam at McHenry helps to minimize damage to property and loss of life upstream and downstream from McHenry. The Illinois Department of Natural Resources, Office of Water Resources (IDNR-OWR) has operated the dam at McHenry since 1939 (Illinois Department of Natural Resources, 2012). In 2014, the U.S. Geological Survey (USGS); IDNR-OWR; and National Weather Service, North Central River Forecast Center (NWS) began a cooperative study to develop a system to enable engineers and planners to simulate and communicate flows and to prepare proactively for precipitation events in near real time in the upper Fox River watershed.

The hydrologic gages established along the Fox River in northeastern Illinois are of two types (table 1). All gages on lakes (USGS station numbers 05547000,05547500 , and 05548000) are stage-only gages. Gages on the Fox River (USGS station numbers 05548500, 05549500, and 05549501) are also stage-only. The only streamflow-gaging station in the area is on Nippersink Creek (USGS station number 05548280).

In this study, the Hydrologic Engineering CenterReservoir System Simulation (HEC-ResSim) program (U.S. Army Corps of Engineers, 2013) was used as the primary tool for Chain of Lakes reservoir modeling. Although the Chain of Lakes consists of several lakes, the lakes are connected in a way such that they can be modeled as a single reservoir. The nonequivalence and nonlinear relation of the reservoir pool elevation and dam headwater elevation in the Chain of Lakes does not allow for the direct implementation of the dam at McHenry within the modeling software. A satisfactory relation between reservoir pool elevation and dam headwater elevation was found using flow, gage height 




Figure 1. Real-time streamgage stations in and near the Chain of Lakes on the Fox River in northeastern Illinois. The Chain of Lakes is composed of a series of connected lakes, six of which are labeled in the figure. 
Table 1. Hydrologic stations near the Chain of Lakes on the Fox River in northeastern Illinois.

[Station 05549500 is 300 feet upstream from Stratton Dam and station 05549501 is 30 feet downstream from the dam. Stage is gage height at the station. USGS, U.S. Geological Survey; $\mathrm{mi}^{2}$, square mile; na, not applicable]

\begin{tabular}{lccl}
\hline \multicolumn{1}{c}{ USGS station name } & USGS station number & $\begin{array}{c}\text { Drainage area } \\
\left(\mathbf{m i} \mathbf{2}^{\mathbf{2}}\right.\end{array}$ & Type of gage \\
\hline Channel Lake near Antioch, Ill. & 05547000 & na & Stage only; no streamflow \\
Fox Lake near Lake Villa, Ill. & 05547500 & na & Stage only; no streamflow \\
Nippersink Lake at Fox Lake, Ill. & 05548000 & na & Stage only; no streamflow \\
Nippersink Creek near Spring Grove, Ill. & 05548280 & 192 & Streamflow-gaging station \\
Fox River at Johnsburg, Ill. & 05548500 & 1,205 & Stage only; no streamflow \\
Fox River near McHenry, Ill. & 05549500 & 1,250 & Stage only; no streamflow \\
Fox River (tailwater) near McHenry, Ill. & 05549501 & 1,250 & Stage only; no streamflow \\
\hline
\end{tabular}

at Fox Lake near Lake Villa, Ill. (05547500), and fall between Fox Lake near Lake Villa, Ill. (05547500), and Fox River near McHenry, Ill. (05549500). The implementation of the physical limitations of the outlet release capacity is handled by scripted rules. Scripted rules were used to set physical limits instead of the usual HEC-ResSim physical limit settings because of the complex relation between the dam headwater and pool elevations. Reservoir operation guidelines were taken from the operation manual by Illinois Department of Natural Resources (2012).

In order to evaluate the performance of the reservoir model, the NWS supplied an inflow time series for the reservoir model from their Community Hydrology Prediction System (CHPS) (Justin Palmer, National Weather Service, written commun., August 2015). These predicted inflows are considered as close to observed inflows as possible and are a direct match to the inflows produced by CHPS on an operational basis. From these results, nine periods during high pool elevation were chosen. The simulated peak elevations from these time periods were graphically compared to the closest-in-time observed pool elevation peak. The peak elevation prediction ability was also evaluated by calculating the Nash-Sutcliffe model efficiency coefficient (Nash and Sutcliffe, 1970). The overall usefulness of the model was graphically evaluated by plotting the simulated elevation time series with the observed elevation time series during nine periods of high reservoir pool elevation. Evaluation of the model based on accuracy of peak prediction and the ability to simulate an elevation time series showed the performance of the model was satisfactory.

\section{Purpose and Scope}

The purpose of this report is to document the development and evaluation of the Chain of Lakes reservoir model. The creation of the reservoir model is a part of a larger project to develop a system to enable engineers and planners to simulate and communicate flows and to prepare proactively for precipitation events in near real time. The reservoir model described in this report allows IDNR-OWR to optimize the operation of the dam at McHenry using predicted inflows from the NWS. The development of this new reservoir model improves the current IDNR-OWR operation workflow by allowing the operational simulation to be on the same time scale as the NWS forecast simulation.

\section{Model Development}

The HEC-ResSim program (U.S. Army Corps of Engineers, 2013) was used as the primary tool for Chain of Lakes reservoir modeling. Two major modeling concepts in HEC-ResSim are (1) physical component definitions, such as storage capacity of the reservoir and release capacity of the reservoir outlet; and (2) operational data, which define operational decisions developed from policy.

\section{Physical Component Definitions}

The inlet of the reservoir model is at Wilmot, Wis., and the outlet is at Johnsburg, Ill. (fig. 1). These locations were chosen to correspond to the NWS CHPS basin outlet at Johnsburg (NWS basin code JHNI2) and 1 of 2 basin inlets at Wilmot (NWS basin code WMTW3). For the Chain of Lakes reservoir model, the storage of the reservoir pool and the release capacity of the reservoir outlet are the physical components that are defined in the following sections.

\section{Reservoir Pool}

Although the Chain of Lakes reservoir consists of several lakes, it is modeled as a single reservoir with a simple storage-elevation relation because the lakes are directly hydraulically connected. The storage-elevation curve (fig. 2) 


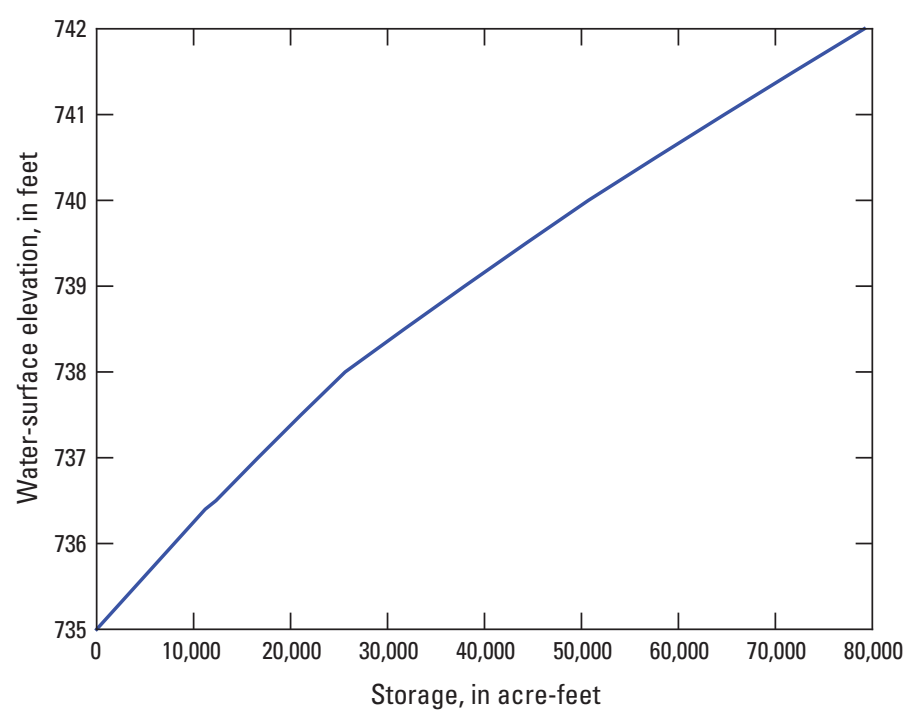

Figure 2. Storage-elevation curve for the Chain of Lakes reservoir on the Fox River in northeastern Illinois (modified from Illinois Department of Natural Resources, 2012). Water-surface elevation is referenced to the National Geodetic Vertical Datum of 1929.

is from the operation manual for the dam at McHenry (Illinois Department of Natural Resources, 2012).

\section{Release Capacity}

In the HEC-ResSim program, the physical release capacity of a reservoir outlet is modeled as a function of the reservoir pool elevation with the assumption that the outlet headwater elevation is the same as or equivalent to the pool elevation (U.S. Army Corps of Engineers, 2013). Because of the distance between the outlet of the reservoir at Pistakee Lake and the dam at McHenry (fig. 1), releases from the reservoir travel through an open channel and experience a head loss. The head loss makes the reservoir pool and outlet headwater elevations nonequivalent. The nonequivalence and nonlinear relation of the reservoir pool elevation and dam headwater elevation in the Chain of Lakes does not allow for the direct implementation of the McHenry dam within the model. Because of the complex relation between the headwater elevation of the dam at McHenry (at Fox River near McHenry, Ill. [05549500]), the reservoir pool elevation at Fox Lake near Lake Villa, Ill. (05547500), and streamflow between the reservoir outlet and the dam (fig. 3), defining the physical limits on the release of the reservoir requires a more complex description.

A satisfactory relation using flow at Fox River near McHenry, Ill. (05549500), and Fox River near Johnsburg, Ill. (05548500); gage height at Fox Lake near Lake Villa, Ill. (05547500); and fall between Fox Lake near Lake Villa, Ill.
(05547500), and Fox River near McHenry, Ill. (05549500), was found and is described in the "Linear Regressions" section. Headwater elevation in the control structure ratings (Straub and others, 2009) at the dam is predicted by using the gage height-flow-fall relation. These control structure ratings also need a tailwater elevation. An additional gage height-flow relation was found using Fox River (tailwater) near McHenry, Ill. (05549501), as discussed further in the "Linear Regressions" section. The control structure ratings are used to set physical limitations on release capacity.

As modeled in HEC-ResSim, the reservoir outlet serves as a dummy dam with a single controlled outlet. The implementation of the physical limitations of the control structure release capacity is handled by scripted rules. The scripted rules are described in the "Scripted Physical Limit Rules" section. The release capacity of the outlet is set unrealistically high in order to avoid interference with the physical limits that are set by scripted rules.

\section{Linear Regressions}

Two linear regression models were developed for use in the reservoir model. The first was a gage height-flow-fall model to predict headwater at the McHenry control structure. The concept of using fall, defined as the difference in watersurface elevation between two gages, as an explanatory variable in a rating is from Kennedy (1984). This gage height-flow-fall relation is used to predict a control structure headwater elevation, as well as a maximum flow, from fall. Because the linear regression model is used to predict flow and fall, a geometric mean functional relationship (GMFR) regression method (Draper and Yang, 1997), which considers error in all variables, was used. The second linear regression model was a gage height-flow model for the tailwater elevation of the dam at McHenry. The tailwater gage heightflow relation is also used to predict flow from an observed gage height time series. Like the gage height-flow-fall relation, the tailwater gage height-flow relation was found by using a GMFR. In a two-dimensional context, the relation is also referred to as the line of organic correlation (Helsel and Hirsch, 2002). All variables were transformed into base- 10 logarithmic space.

\section{Variables}

A total of four variables are used in the two linear regressions. The variables are flow $(Q)$, in cubic feet per second; gage height at Lake Villa $\left(G_{L V}\right)$, in feet; fall $(F)$, in feet; and tailwater gage height at McHenry $\left(G_{T W}\right)$, in feet. In the Chain of Lakes model, the fall is defined as

$$
F=G_{L V}-G_{H W}
$$

where $G_{H W}$ is the headwater gage height at McHenry, in feet. Because the gage heights at Lake Villa and headwater at McHenry have the same datum (733.00 feet [ft]), equation 1 is 


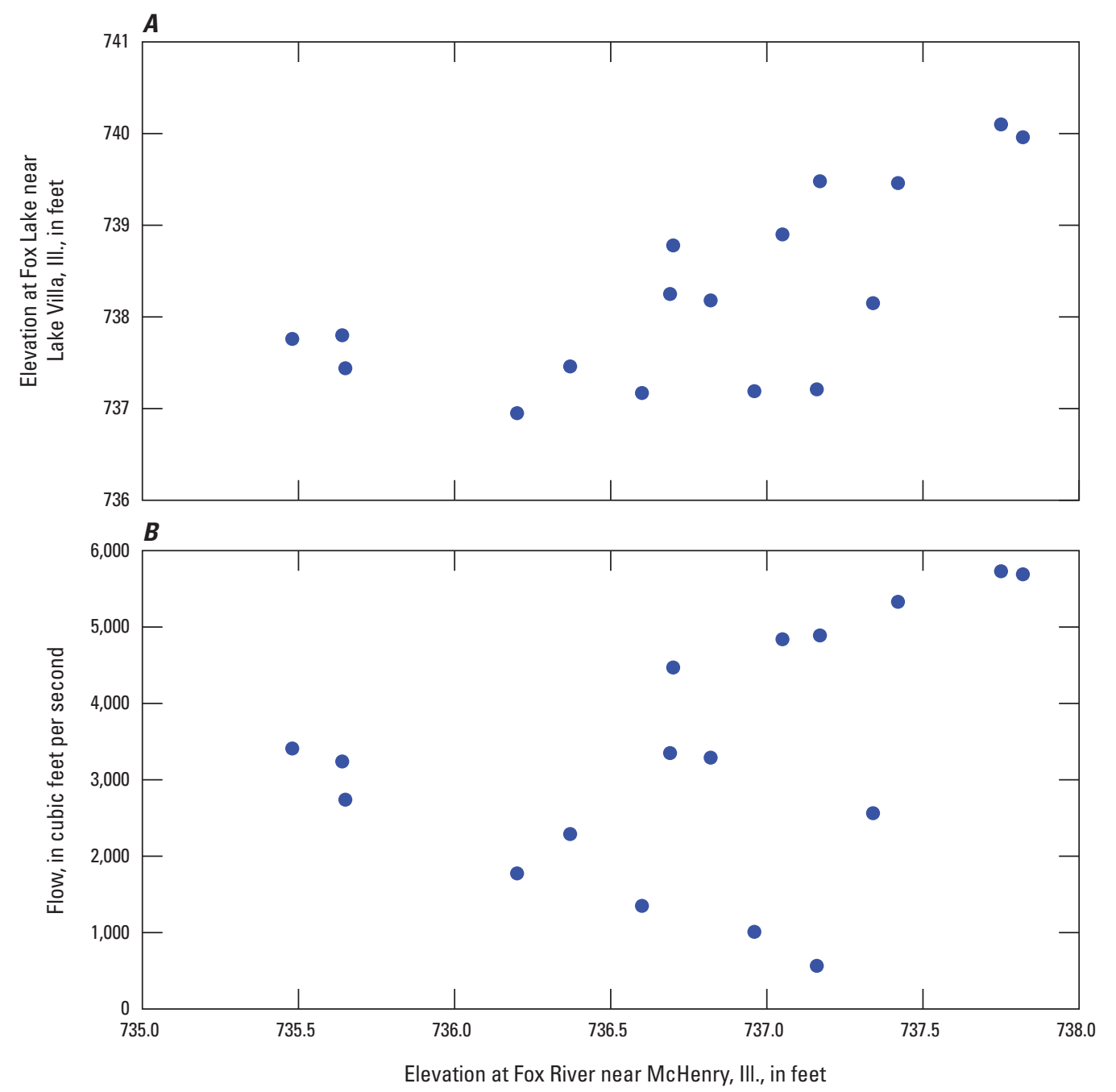

Figure 3. Complex relation between $A$, reservoir pool elevation at Fox Lake near Lake Villa, Illinois (05547500), and water-surface elevation at Fox River near McHenry, III. (05549500), and B, flow at Fox River near McHenry, III. (05549500), and Fox River near Johnsburg, III. (05548500), and water-surface elevation at Fox River near McHenry, III. (05549500). Water-surface elevation is referenced to the National Geodetic Vertical Datum of 1929.

equivalent to the difference in water-surface elevation between the two gages.

The $Q, G_{L V}$, and $F$ are used in the regression for the McHenry headwater relation. The $Q$ and $G_{T W}$ are used in the regression for the McHenry tailwater relation. Figure 4 shows a descriptive diagram of the variables, and table 2 gives a description of each variable.

The relation between $Q, F$, and $G_{L V}$ is assumed to be independent of time. The tailwater gage height-flow relation is also assumed to be independent of time. This assumption simplifies the reservoir simulation and can be made because of the spatial proximity and direct hydraulic connection of the McHenry and Lake Villa gages.

\section{Model Observations}

The observations used to estimate the parameters in the linear regression models are shown in table 3. Measurements taken prior to the installation of the hinged-crest gate in 2002 were not used as observations.

Quantile and seasonality plots of the real-time variables with the locations of observations used in the indicated models are shown in figure 5. The time series used in the plots are instantaneous observations with a 6-hour interval. The time period of the series begins March 24, 2003, and ends December 31, 2013, with intermittent missing observations. Approximately 790 from 15,740 observations are missing within the time period. Missing observations occur because of gage outages. 


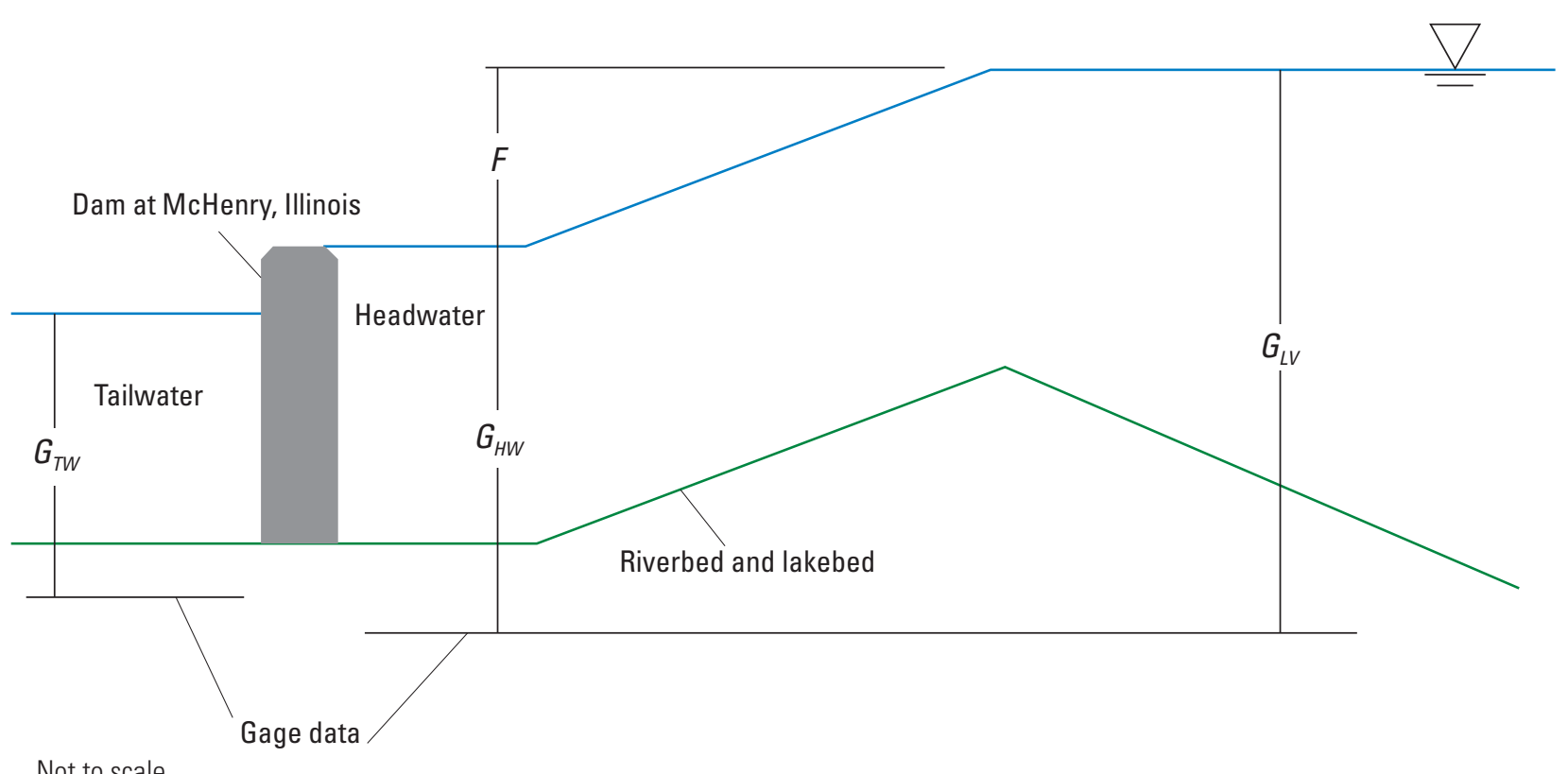

Figure 4. The relation between the gage height and fall variables used in the linear regression models for the outlet of the Chain of Lakes reservoir on the Fox River in northeastern Illinois. [F, water-surface elevation fall between Fox Lake near Lake Villa, III. (05547500), and Fox River near McHenry, III. (05549500); $G_{\mathrm{LV}^{\prime}}$ gage height at Fox Lake near Lake Villa, III. (05547500); $\mathrm{G}_{\mathrm{HW}}$ gage height (headwater) at Fox River near McHenry, III. (05549500); $\mathrm{G}_{\mathrm{TW}}$ gage height (tailwater) at Fox River near McHenry, III. (05549501); Headwater, the water upstream from the dam at McHenry, III.; Tailwater, the water downstream from the dam at McHenry, III.]

Table 2. Description of variables used in the linear regression models for the outlet of the Chain of Lakes reservoir on the Fox River in northeastern Illinois.

\begin{tabular}{clc}
\hline Variable & \multicolumn{1}{c}{ Variable description } & Unit \\
\hline $\mathrm{G}_{L V}$ & $\begin{array}{c}\text { Gage height at 05547500 Fox Lake near } \\
\text { Lake Villa, Ill. }\end{array}$ & feet \\
& $\begin{array}{c}\text { Gage height at 05549501 Fox River } \\
\text { (tailwater) near McHenry, Ill. }\end{array}$ & feet \\
& Water-surface elevation fall & feet \\
$F$ & Flow & $\begin{array}{r}\text { cubic feet } \\
\text { per second }\end{array}$ \\
$Q$ & & per
\end{tabular}

Observations of McHenry tailwater gage height and fall have been made for a wide range of quantiles as shown in figures $5 A, C$, and $E$. A lack of observations in the lower quartile of Fox Lake gage heights is shown in figure $5 C$.

Negative fall values have been observed but are infrequent (fig. $5 E$ ). One cause of negative fall values is strong winds from the southwest (Schrader and Holmes, 2000). Another cause may be the unsteady effects that are not considered within the context of the reservoir model. The probability of a negative fall value occurring, estimated from the observed time series (fig. $5 E$ ), is 5 percent. Because all variables have been logarithmically transformed in the regression, the resulting linear regression model will not predict and is unable to accommodate negative fall values.

The seasonal occurrence of observations is shown in figures $5 B, D$, and $F$. Measurements that are used as observations in the model occurred throughout the year, resulting in a satisfactory seasonal range; however, figures $5 B$, $D$, and $F$ show a lack of observations during the winter pool period, with only one observation being made in January. Eight observations were made during seasonal transition periods of dam operation.

\section{McHenry Headwater Relation}

A relation was found to predict the McHenry headwater elevation using a gage height-flow-fall regression model. Measured flow $(Q)$, the real-time gage height at Fox Lake near Lake Villa, Ill. $\left(G_{L V}\right)$, and fall $(F)$ calculated from realtime gage height observations were used as the variables. The equations with the estimated coefficients for each variable are given in equations $2-4$. 
Table 3. Observations used in the development of the linear regression models. See table 1 for station names.

[USGS, U.S. Geological Survey; $\mathrm{ft}^{3} / \mathrm{s}$, cubic feet per second; ft, feet]

\begin{tabular}{|c|c|c|c|c|c|c|c|}
\hline \multirow{2}{*}{$\begin{array}{l}\text { Measurement } \\
\text { station number }\end{array}$} & \multirow{2}{*}{$\begin{array}{l}\text { USGS measure- } \\
\text { ment number }\end{array}$} & \multirow[t]{2}{*}{ Date } & \multirow{2}{*}{$\begin{array}{l}\text { Measured flow } \\
\left(\mathrm{ft}^{3} / \mathrm{s}\right)\end{array}$} & \multicolumn{3}{|c|}{$\begin{array}{l}\text { Gage height } \\
\text { (ft) }\end{array}$} & \multirow{2}{*}{$\begin{array}{l}\text { Fall } \\
\text { (ft) }\end{array}$} \\
\hline & & & & 05549500 & 05549501 & 05547500 & \\
\hline 05549500 & 44 & $11 / 18 / 2002$ & 565 & 4.16 & 1.03 & 4.21 & 0.05 \\
\hline 05549500 & 45 & $11 / 19 / 2002$ & 1,010 & 3.96 & 1.07 & 4.19 & 0.23 \\
\hline 05549500 & 46 & $11 / 19 / 2002$ & 1,350 & 3.60 & 1.64 & 4.17 & 0.57 \\
\hline 05549500 & 47 & $11 / 20 / 2002$ & 1,775 & 3.20 & 2.09 & 3.95 & 0.75 \\
\hline 05549500 & 49 & $05 / 17 / 2004$ & 2,563 & 4.34 & 3.50 & 5.15 & 0.81 \\
\hline 05549500 & 51 & $05 / 17 / 2004$ & 3,290 & 3.82 & 4.01 & 5.18 & 1.36 \\
\hline 05549500 & 52 & $05 / 24 / 2004$ & 4,840 & 4.05 & 5.84 & 5.90 & 1.85 \\
\hline 05548500 & 26 & $05 / 28 / 2004$ & 5,330 & 4.42 & 5.97 & 6.46 & 2.04 \\
\hline 05549500 & 53 & $03 / 17 / 2006$ & 2,740 & 2.65 & 3.78 & 4.44 & 1.79 \\
\hline 05549500 & 54 & $03 / 17 / 2006$ & 2,290 & 3.37 & 3.32 & 4.46 & 1.09 \\
\hline 05549500 & 55 & $03 / 16 / 2007$ & 3,240 & 2.64 & 4.32 & 4.80 & 2.16 \\
\hline 05549500 & 56 & $08 / 22 / 2007$ & 4,470 & 3.70 & 5.45 & 5.78 & 2.08 \\
\hline 05549500 & 57 & $08 / 27 / 2007$ & 5,690 & 4.82 & 6.95 & 6.96 & 2.14 \\
\hline 05549500 & 58 & $03 / 26 / 2008$ & 3,410 & 2.48 & 4.38 & 4.76 & 2.28 \\
\hline 05549500 & 59 & $04 / 16 / 2008$ & 4,890 & 4.17 & 6.04 & 6.48 & 2.31 \\
\hline 05549500 & 60 & $06 / 20 / 2008$ & 5,730 & 4.75 & 6.78 & 7.10 & 2.35 \\
\hline 05549500 & 61 & $01 / 02 / 2009$ & 3,350 & 3.69 & 4.99 & 5.25 & 1.56 \\
\hline
\end{tabular}

$$
\begin{gathered}
Q=254.86 G_{L V}^{1.4372} F^{0.43181} \\
F=2.6755 \times 10^{-6} G_{L V}^{-3.3283} Q^{2.3158} \\
G_{L V}=2.1169 \times 10^{-2} F^{-0.30045} Q^{0.69581}
\end{gathered}
$$

The values for the measured and computed variables are shown in table 4 . The computed values plotted against the measured variables are shown in figure 6 . There is little deviation from the line of perfect agreement, or the 1:1 line. The Nash-Sutcliffe model efficiencies (Nash and Sutcliffe, 1970) for all three variables (table 5) demonstrate the predictive power of the linear regression models. The lowest efficiency for the prediction of water-surface elevation fall is 0.90 .

\section{McHenry Tailwater Relation}

A McHenry tailwater relation was found using a gage height-flow regression model. Flow and gage height at Fox River (tailwater) near McHenry, Ill., were used as variables. Equations 5 and 6 give the retransformed equations with estimated coefficients. A scatter plot of the model observations, along with a fit line, is shown in figure 7.

$$
\begin{gathered}
Q=712.50 G_{T W}^{1.0696} \\
G_{T W}=2.1520 \times 10^{-3} Q^{0.93493}
\end{gathered}
$$

The values for the measured and computed variables are given in table 6 . The computed values plotted against the measured variables on logarithmically scaled axes are shown in figure 8 . Although there is good agreement between computed and measured variables in general, the relative error in the low range of observations is higher for both variables. Despite this, the computed Nash-Sutcliffe model efficiency (table 7) for both variables is close to one. The lowest efficiency, calculated for the tailwater gage height, is 0.97 .

\section{Estimating Water-Surface Elevations}

During a computation of a reservoir simulation, the headwater elevation $\left(Z_{H W}\right)$ is estimated using the relation described in the "McHenry Headwater Relation" subsection in the "Linear Regressions" section. In this relation, the flow and pool gage height from the previous time step are used. The pool gage height is calculated by subtracting the gage datum from the simulated pool elevation $\left(Z_{L V}\right)$.

$$
G_{L V}=Z_{L V}-733.00
$$




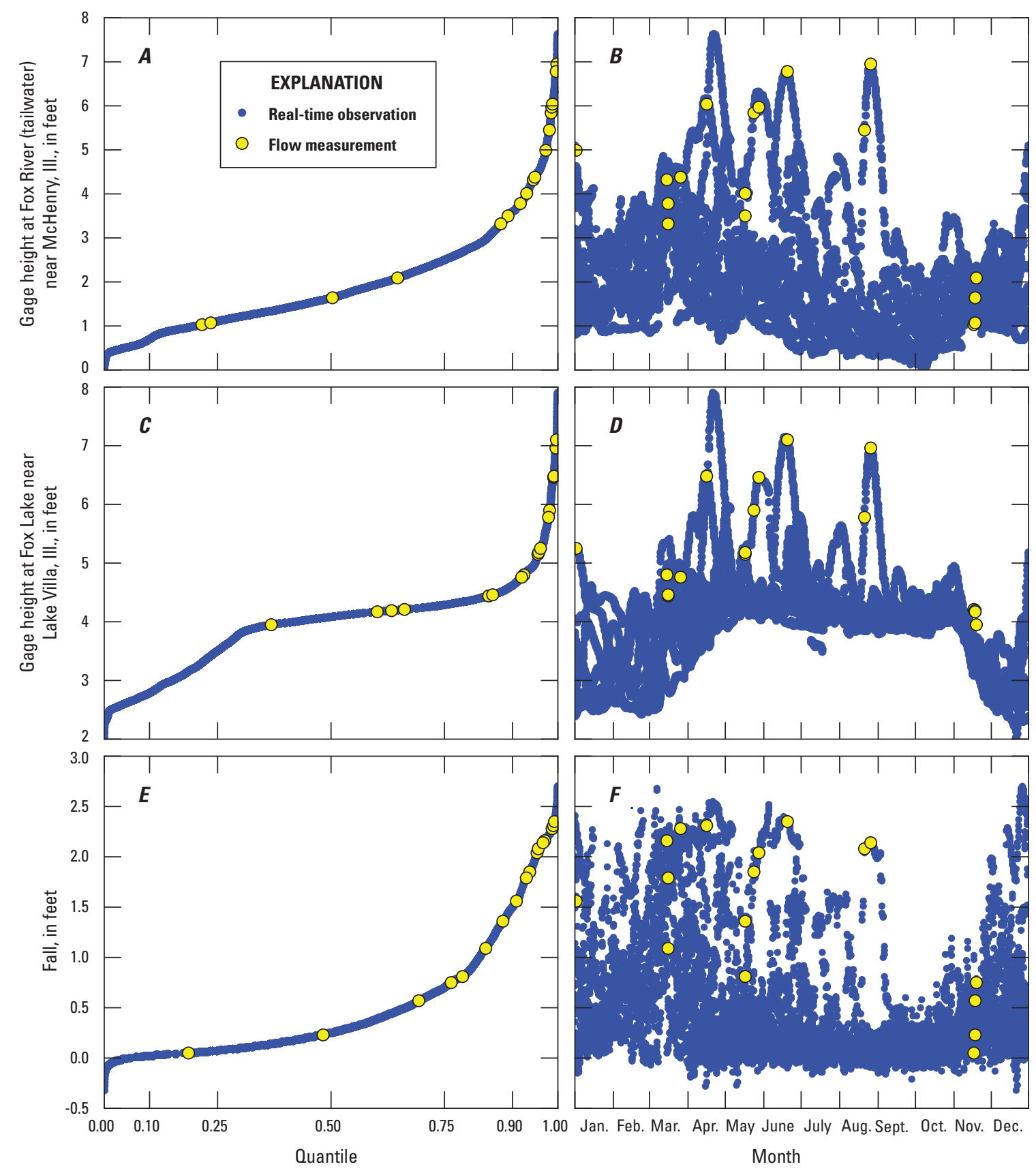

Figure 5. Distributional and seasonal characteristics of the real-time variables used in the development of the linear regression models for the Chain of Lake reservoir on the Fox River in northeastern Illinois. $A$, distributional and $B$, seasonal characteristics of gage height at Fox River (tailwater) near McHenry, III. (05549501); $C$, distributional and $D$, seasonal characteristics of gage height at Fox Lake near Lake Villa, III. (05547500); and $E$, distributional and $F$, seasonal characteristics of water-surface elevation fall between Fox Lake near Lake Villa, III. (05547500), and Fox River near McHenry, III. (05549500). 
Table 4. Measured and computed observations of the variables for the gage height-flow-fall model used at the Fox River near McHenry, Illinois (05549500), streamgage. See table 1 for station names.

[USGS, U.S. Geological Survey, Q, flow; ft³/s, cubic feet per second; $\mathrm{G}_{\mathrm{LV}}$, gage height at Fox Lake near Lake Villa, Ill.; ft, feet; F, water-surface elevation fall]

\begin{tabular}{|c|c|c|c|c|c|c|c|c|}
\hline $\begin{array}{l}\text { Measurement } \\
\text { station number }\end{array}$ & $\begin{array}{l}\text { USGS measure- } \\
\text { ment number }\end{array}$ & Date & $\begin{array}{l}\text { Measured } 0 \\
\left(\mathrm{ft}^{3} / \mathrm{s}\right)\end{array}$ & $\begin{array}{c}\text { Computed } 0 \\
\left(\mathrm{ft}^{3} / \mathrm{s}\right)\end{array}$ & $\begin{array}{l}\text { Measured } \mathbf{G}_{\mathrm{Lv}} \\
\text { (ft) }\end{array}$ & $\begin{array}{c}\text { Computed } \mathbf{G}_{\mathrm{LV}} \\
\text { (ft) }\end{array}$ & $\begin{array}{l}\text { Measured F } \\
\text { (ft) }\end{array}$ & $\begin{array}{c}\text { Computed F } \\
\text { (ft) }\end{array}$ \\
\hline 05549500 & 44 & $11 / 18 / 2002$ & 565 & 552 & 4.21 & 4.28 & 0.05 & 0.05 \\
\hline 05549500 & 45 & $11 / 19 / 2002$ & 1,010 & 1,059 & 4.19 & 4.05 & 0.23 & 0.21 \\
\hline 05549500 & 46 & $11 / 19 / 2002$ & 1,350 & 1,557 & 4.17 & 3.78 & 0.57 & 0.41 \\
\hline 05549500 & 47 & $11 / 20 / 2002$ & 1,775 & 1,621 & 3.95 & 4.21 & 0.75 & 0.93 \\
\hline 05549500 & 49 & 05/17/2004 & 2,563 & 2,454 & 5.15 & 5.31 & 0.81 & 0.90 \\
\hline 05549500 & 51 & $05 / 17 / 2004$ & 3,290 & 3,095 & 5.18 & 5.41 & 1.36 & 1.57 \\
\hline 05549500 & 52 & $05 / 24 / 2004$ & 4,840 & 4,261 & 5.90 & 6.45 & 1.85 & 2.48 \\
\hline 05548500 & 26 & $05 / 28 / 2004$ & 5,330 & 5,064 & 6.46 & 6.69 & 2.04 & 2.30 \\
\hline 05549500 & 53 & $03 / 17 / 2006$ & 2,740 & 2,792 & 4.44 & 4.38 & 1.79 & 1.71 \\
\hline 05549500 & 54 & 03/17/2006 & 2,290 & 2,268 & 4.46 & 4.49 & 1.09 & 1.11 \\
\hline 05549500 & 55 & $03 / 16 / 2007$ & 3,240 & 3,387 & 4.80 & 4.65 & 2.16 & 1.95 \\
\hline 05549500 & 56 & $08 / 22 / 2007$ & 4,470 & 4,352 & 5.78 & 5.89 & 2.08 & 2.21 \\
\hline 05549500 & 57 & $08 / 27 / 2007$ & 5,690 & 5,754 & 6.96 & 6.91 & 2.14 & 2.09 \\
\hline 05549500 & 58 & $03 / 26 / 2008$ & 3,410 & 3,425 & 4.76 & 4.75 & 2.28 & 2.26 \\
\hline 05549500 & 59 & $04 / 16 / 2008$ & 4,890 & 5,367 & 6.48 & 6.07 & 2.31 & 1.86 \\
\hline 05549500 & 60 & 06/20/2008 & 5,730 & 6,165 & 7.10 & 6.75 & 2.35 & 1.98 \\
\hline 05549500 & 61 & $01 / 02 / 2009$ & 3,350 & 3,347 & 5.25 & 5.25 & 1.56 & 1.56 \\
\hline
\end{tabular}

Fall is estimated from equation 3, using the simulated reservoir pool gage height and the flow from the previous time step. Headwater elevation at the McHenry dam is found by subtracting the estimated fall from the simulated pool elevation.

$$
Z_{H W}=Z_{L V}-F
$$

For the tailwater elevation, the gage height for the current time step is estimated from equation 6 , using the flow from the previous time step. The tailwater elevation $\left(Z_{T W}\right)$ is calculated by adding the estimated gage height to the gage datum. The tailwater gage datum is $730.15 \mathrm{ft}$.

$$
Z_{T W}=G_{T W}+730.15
$$

Once the headwater and tailwater elevations are found, the headwater and tailwater heights for each control structure within the dam are calculated by subtracting the corresponding reference elevations as described in the "Control Structure Ratings" section.

\section{Control Structure Ratings}

The release capacity of the dam at the reservoir outlet is calculated based on the ratings for the control structures at the McHenry dam (Straub and others, 2009). The ratings require headwater height, tailwater height, and gate settings in order to calculate flow. There are different headwater and tailwater heights for each control structure at the dam, as described in the following sections.

\section{Broad-Crested Weir}

The broad-crested weir headwater and tailwater heights, $h_{1_{B C W}}$ and $h_{B_{B C W}}$, respectively, are found by subtracting the elevation of the top of the broad-crested weir $(736.68 \mathrm{ft})$ from the headwater and tailwater elevations estimated from the linear regression relations.

$$
h_{1_{B C W}}=Z_{H W}-736.68
$$

$$
h_{3_{B C W}}=Z_{T W}-736.68
$$

\section{Hinged-Crest Gate}

The hinged-crest gate headwater and tailwater heights, $h_{1_{H C G}}$ and $h_{3_{H C G}}$, respectively, are found by subtracting the elevation of the top of the hinged-crest gate $\left(Z_{H C G}\right)$ at the opened or closed position, depending on the maximum or minimum limit, from the estimated water-surface elevations. 

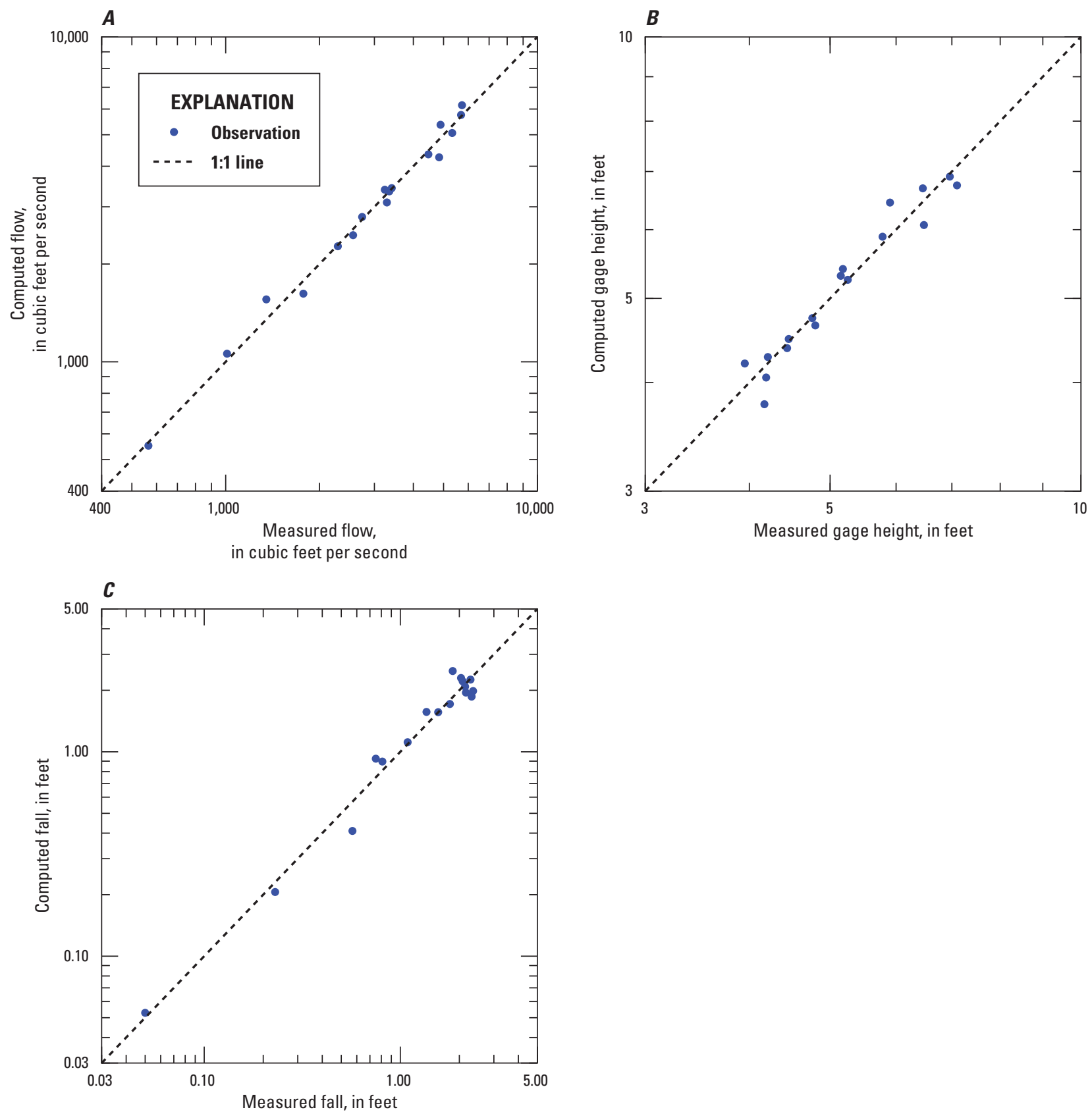

Figure 6. Measured and computed $A$, flow, $B$, gage height at Fox River near McHenry, Illinois (05549500), and $C$, watersurface elevation fall between Fox Lake near Lake Villa, III. (05547500), and Fox River near McHenry, III. (05549500).

The top elevation of the hinged-crest gate is calculated by adding the concrete slab elevation (730.08 ft) and the hinged-crest gate setting $\left(p_{H C G}\right)$.

$$
\begin{aligned}
& h_{1_{H C G}}=Z_{H W}-Z_{H C G} \\
& h_{3_{H C G}}=Z_{T W}-Z_{H C G}
\end{aligned}
$$

where

$$
Z_{H C G}=p_{H C G}+730.08 \text {. }
$$

For the physical limit scripted rules, the hinged-crest gate setting $p_{H C G}$ varies from the fully opened position of $0.42 \mathrm{ft}$ for the maximum flow limit to fully the closed setting of $7.12 \mathrm{ft}$ for the minimum flow limit. 
Table 5. Nash-Sutcliffe model efficiency coefficient calculated for the variables in the gage height-flow-fall used at the Fox River near McHenry, Illinois (05549500), streamgage.

\begin{tabular}{lc}
\hline \multicolumn{1}{c}{ Variable } & Nash-Sutcliffe efficiency \\
\hline Flow & 0.98 \\
Gage height at Fox Lake near Lake Villa, Ill. (05547500) & 0.94 \\
Water-surface elevation fall & 0.90 \\
\hline
\end{tabular}

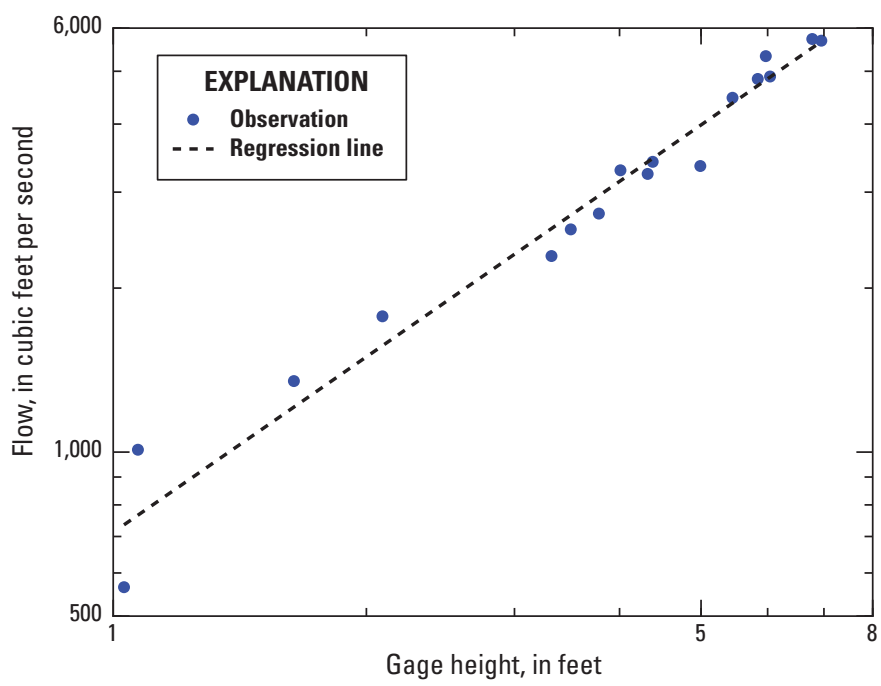

Figure 7. Flow-gage height model for observations at Fox River (tailwater) near McHenry, Illinois (05549501).

Table 6. Measured and computed observations of the variables for the flow-gage height model used at the Fox River (tailwater) near McHenry, Illinois (05549501), streamgage. See table 1 for station names.

[USGS, U.S. Geological Survey; Q, flow; ft³/s, cubic feet per second; $\mathrm{G}_{\mathrm{TW}}$, gage height at Fox River (tailwater) near McHenry, Ill.; ft, feet]

\begin{tabular}{|c|c|c|c|c|c|c|}
\hline $\begin{array}{l}\text { Measurement } \\
\text { station number }\end{array}$ & $\begin{array}{l}\text { USGS measure- } \\
\text { ment number }\end{array}$ & Date & $\begin{array}{c}\text { Measured } 0 \\
\left(\mathrm{ft}^{3} / \mathrm{s}\right)\end{array}$ & $\begin{array}{c}\text { Computed } 0 \\
\left(\mathrm{ft}^{3} / \mathbf{s}\right)\end{array}$ & $\underset{\text { (ft) }}{\text { Measured }} \mathbf{G}_{\mathrm{TW}}$ & $\underset{\text { (ft) }}{\text { Computed } G_{\mathrm{TW}}}$ \\
\hline 05549500 & 44 & $11 / 18 / 2002$ & 565 & 735 & 1.03 & 0.81 \\
\hline 05549500 & 45 & $11 / 19 / 2002$ & 1,010 & 766 & 1.07 & 1.39 \\
\hline 05549500 & 46 & $11 / 19 / 2002$ & 1,350 & 1,209 & 1.64 & 1.82 \\
\hline 05549500 & 47 & $11 / 20 / 2002$ & 1,775 & 1,568 & 2.09 & 2.35 \\
\hline 05549500 & 49 & $05 / 17 / 2004$ & 2,563 & 2,721 & 3.50 & 3.31 \\
\hline 05549500 & 51 & $05 / 17 / 2004$ & 3,290 & 3,147 & 4.01 & 4.18 \\
\hline 05549500 & 52 & $05 / 24 / 2004$ & 4,840 & 4,705 & 5.84 & 6.00 \\
\hline 05548500 & 26 & $05 / 28 / 2004$ & 5,330 & 4,817 & 5.97 & 6.56 \\
\hline 05549500 & 53 & $03 / 17 / 2006$ & 2,740 & 2,955 & 3.78 & 3.52 \\
\hline 05549500 & 54 & $03 / 17 / 2006$ & 2,290 & 2,572 & 3.32 & 2.98 \\
\hline 05549500 & 55 & $03 / 16 / 2007$ & 3,240 & 3,408 & 4.32 & 4.12 \\
\hline 05549500 & 56 & $08 / 22 / 2007$ & 4,470 & 4,370 & 5.45 & 5.57 \\
\hline 05549500 & 57 & $08 / 27 / 2007$ & 5,690 & 5,668 & 6.95 & 6.98 \\
\hline 05549500 & 58 & 03/26/2008 & 3,410 & 3,459 & 4.38 & 4.32 \\
\hline 05549500 & 59 & $04 / 16 / 2008$ & 4,890 & 4,878 & 6.04 & 6.05 \\
\hline 05549500 & 60 & $06 / 20 / 2008$ & 5,730 & 5,520 & 6.78 & 7.02 \\
\hline 05549500 & 61 & $01 / 02 / 2009$ & 3,350 & 3,977 & 4.99 & 4.25 \\
\hline
\end{tabular}



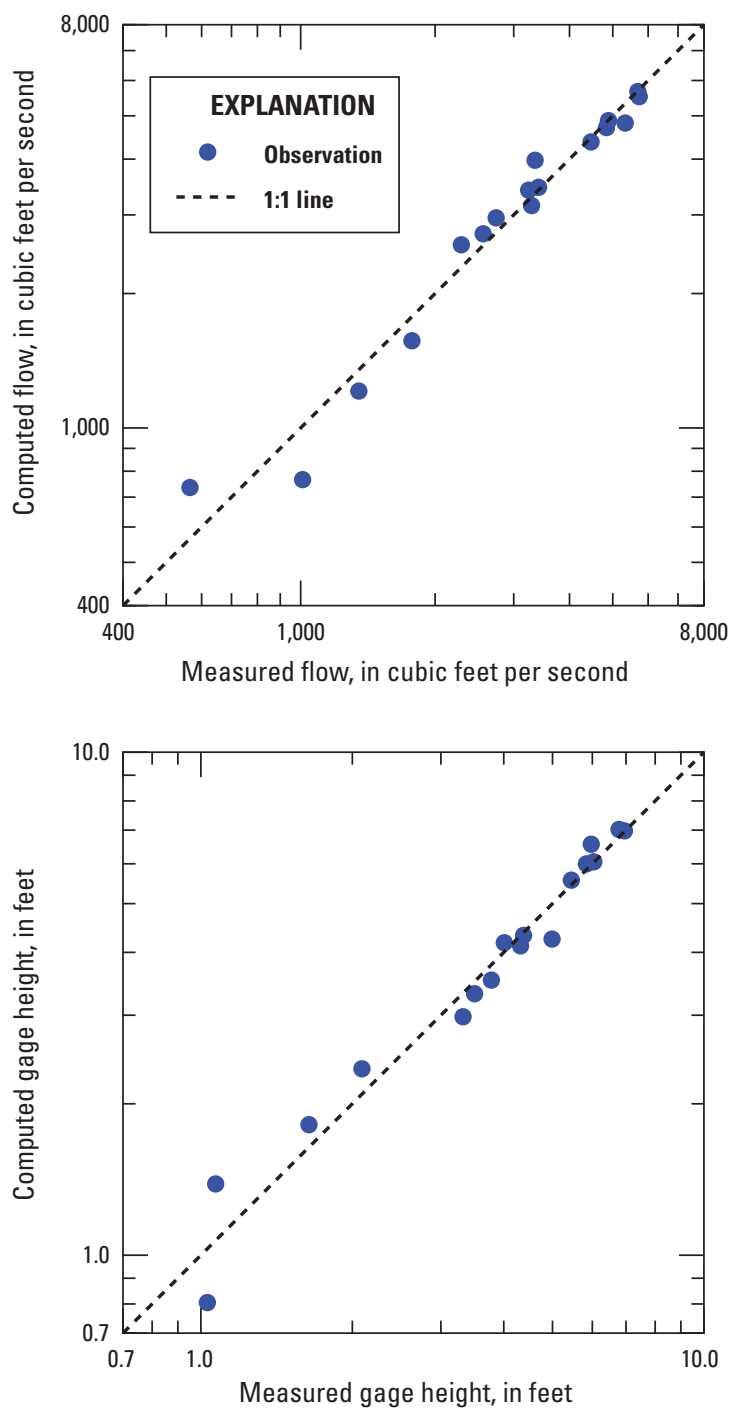

Figure 8. Computed and measured flow and gage height at Fox River (tailwater) near McHenry, Illinois (05549501).

\section{Sluice Gates}

The sluice gate headwater and tailwater heights, $h_{1_{S L}}$ and $h_{3_{S L}}$, are found by subtracting the headwater and tailwater elevations from the elevation of the concrete sill (731.15 ft).

$$
\begin{aligned}
& h_{1_{S L}}=Z_{H W}-731.15 \\
& h_{3_{S L}}=Z_{T W}-731.15
\end{aligned}
$$

When calculating the maximum flow for the maximum controlled and uncontrolled flow rule, flow through the sluice gates is calculated when all of the sluice gate settings $\left(h_{g_{S L}}\right)$
Table 7. Nash-Sutcliffe model efficiency coefficient calculated for the variables in the flow-gage height model used at the Fox River (tailwater) near McHenry, Illinois (05549501), streamgage.

\begin{tabular}{lc}
\hline \multicolumn{1}{c}{ Variable } & $\begin{array}{c}\text { Nash-Sutcliffe } \\
\text { coefficient }\end{array}$ \\
\hline Flow & 0.98 \\
Gage height at Fox River (tailwater) near & 0.97 \\
McHenry, Ill. & \\
\hline
\end{tabular}

are at the fully opened position of $9 \mathrm{ft}$. Flow through the sluice gates is not considered in the minimum uncontrolled flow rule.

\section{Scripted Physical Limit Rules}

Scripted rules exist for physical limits because of the complex relation between the dam headwater and pool elevations. The capacity of the controlled outlet at the dummy dam is regulated by scripted rules that predict the McHenry headwater and tailwater elevations using the gage regression models and the ratings for the control structures at the McHenry dam (Straub and others, 2009). The physical limit rules are summarized in table 8 . These physical limit rules exist in HEC-ResSim as operation rules at the dummy dam, but they function as a proxy for the physical capacity constraints of the outlet.

\section{Minimum Uncontrolled Flow}

The minimum flow physical limit is based on the uncontrolled flow over the broad-crested weir and the hingedcrest gate at the fully closed setting. The minimum flow limit is found by estimating the headwater and tailwater elevations using the linear regression relations described in the "Linear Regressions" section and the equations described in "Estimating Water-Surface Elevations." After the watersurface elevations are estimated, the uncontrolled flow over the hinged-crest gate at the fully closed setting and the broadcrested weir are estimated using the control structure ratings.

Table 8. Physical limit rules in the Chain of Lakes Hydrologic Engineering Center-Reservoir System Simulation (HEC-ResSim) model.

[Min, minimum; Q, flow; BCW, broad-crested weir; HCG, hinged-crest gate; Max, maximum; SL, sluice gate]

\begin{tabular}{ll}
\hline \multicolumn{1}{c}{ Description } & \multicolumn{1}{c}{ Rule name } \\
\hline Minimum uncontrolled flow & Min Q BCW HCG \\
Minimum flow from minimum fall & Min Q from fall \\
Maximum controlled and uncontrolled & Max Q BCW HCG SL \\
$\quad$ flow & \\
Maximum flow from maximum fall & Max Q from fall \\
\hline
\end{tabular}




\section{Minimum Flow from Minimum Fall}

The minimum flow is also restricted by a minimum fall that could occur. In calculating the minimum fall, the fall is first estimated using equation 2 in the "McHenry Headwater Relation" section, using the pool elevation and flow from the previous time step. Next, the fall is calculated between the reservoir pool elevation at the previous time step and the highest overflow elevation of the control structure, which is the average elevation of the broad-crested weir $(736.76 \mathrm{ft})$. The minimum of these two fall estimates is used as the minimum fall. The minimum flow from the minimum fall is calculated using the pool elevation at the previous time step and the minimum fall.

\section{Maximum Controlled and Uncontrolled Flow}

The maximum flow physical limit is based on the release capacity of the McHenry control structures with the sluice gates and hinged-crest gate at the fully opened positions. The uncontrolled flow over the broad-crested weir is also considered. The maximum flow limit is found by estimating the headwater and tailwater elevations using the linear regression relations described in the "Linear Regressions" section and the equations described in the "Estimating Water-Surface Elevations." Once the headwater and tailwater elevations are estimated, the control structure ratings are used to calculate a maximum flow, considering fully open sluice and hinged-crest gates.

\section{Maximum Flow from Maximum Fall}

The maximum flow is also restricted by a maximum fall that could occur. Setting the maximum fall is similar to using the built-in flow rate of change limitation feature within HEC-ResSim. The maximum fall is calculated from the difference between the pool elevation at the previous time step and the greater of the tailwater elevation at the previous time step and the lowest elevation at the dam, which is the hinged-crest gate at the fully opened position (730.50 ft). If this fall is greater than $2 \mathrm{ft}$, then the maximum fall is set to $2 \mathrm{ft}$. The maximum flow from the maximum fall is calculated using the pool elevation at the previous time step and the maximum fall using equation 2 in the "McHenry Headwater Relation" section.

\section{Operational Data}

The reservoir operation guidelines are taken from the operation manual by Illinois Department of Natural Resources (2012). The operational aspects from the HEC-ResSim program that are used in the Chain of Lakes reservoir model include guide curves, operation zones, operation rules, and operation sets. Below are definitions partially excerpted from the HEC-ResSim user's manual (U.S. Army Corps of Engineers, 2013). For a more detailed explanation of operations data, see the HEC-ResSim user's manual.
- Guide curve-A guide curve is a seasonally varying target pool elevation that describes the regulation plan for a reservoir.

- Operation zone-Operation zones are operational subdivisions of the reservoir pool. Each operation zone is defined by an elevation curve describing the top of the zone.

- Operation rule-Operation rules represent the flow goals and constraints upon the releases for each operation zone of the operation set. Rules can be applied to selected zones of the reservoir to describe the different factors influencing the release decision when the reservoir elevation is within each zone.

- Operation set-An operation set is the operation plan or scheme upon which a reservoir bases its decisions regarding how much water to release at each time step of simulation run. Key elements of an operation set include operation zones, guide curve selection, and rules.

\section{Guide Curve}

The HEC-ResSim program calculates reservoir releases based on guide curve operations (U.S. Army Corps of Engineers, 2013). The guide curve serves as the target pool elevation for the operation of the reservoir. The HEC-ResSim implementation of guide curve operations is such that the model will keep the pool at guide curve, or to return it to the guide curve as quickly as possible, by making release decisions at a maximum (or minimum) within the bounds of the operation rules and physical capacities. In the Chain of Lakes ResSim model, the elevation guidelines for the seasonal pool are described in the operation manual for the dam at McHenry (Illinois Department of Natural Resources, 2012).

\section{Operation Zones}

Operation zones are defined by an elevation at the top of the zone. The pool falls within an operation zone when the pool elevation is below the defining elevation for the zone and above the elevation of the next lowest zone. Operation rules are assigned to each zone. When the pool elevation is within a zone, the rules that are assigned to the zone apply in making the release decision. Within the Chain of Lakes reservoir model there are four zones (fig. 9): (1) flood control, (2) standard operations, (3) seasonal pool, and (4) inactive.

\section{Flood Control}

The flood control zone is necessary to implement the scripted physical limit rules, which are the only rules in effect within the zone. In a typical HEC-ResSim implementation that uses a dam to impose physical limits on releases, 


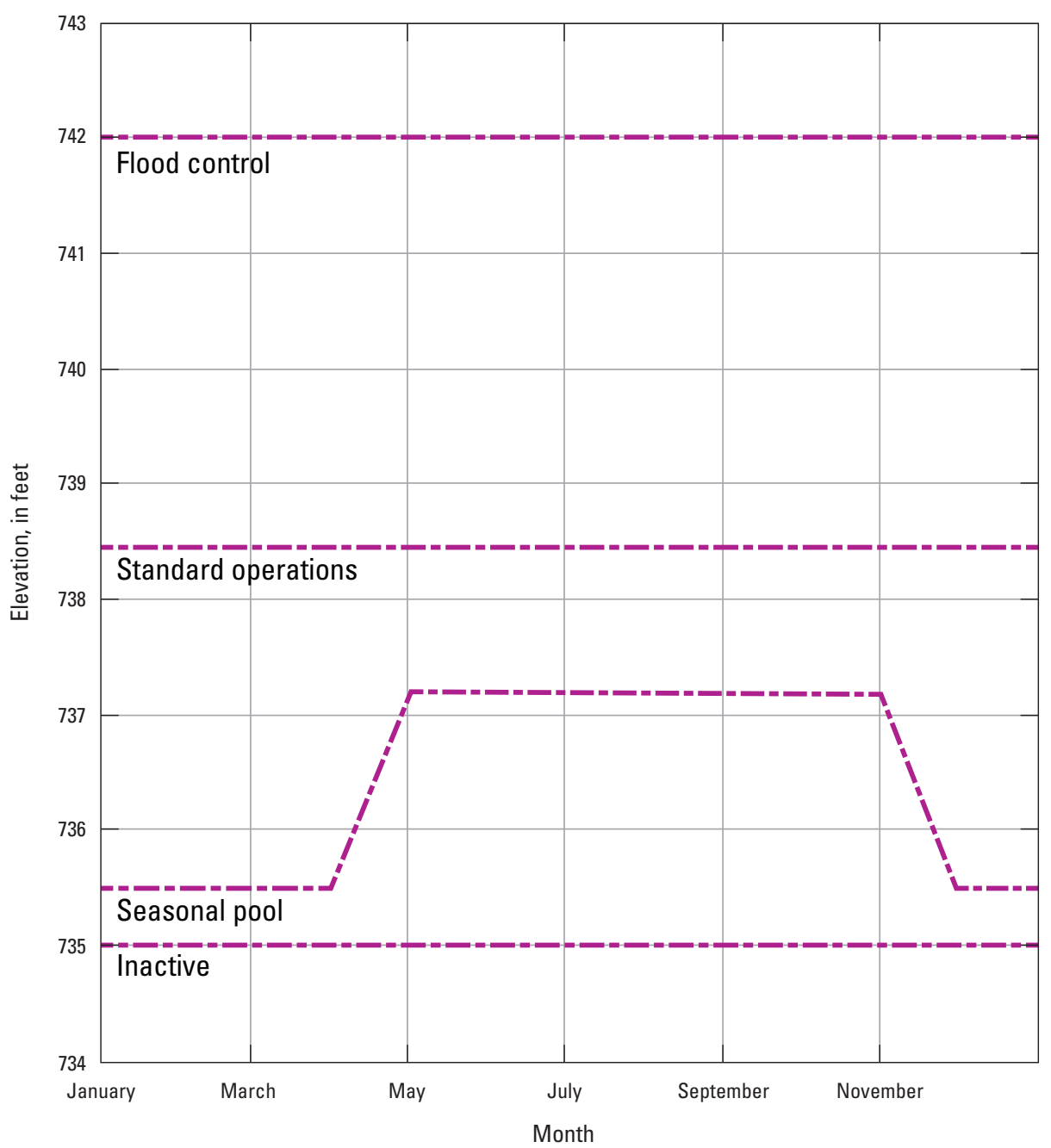

Figure 9. Elevations of operation zones used in the Chain of Lakes reservoir model. Water-surface elevation is referenced to the National Geodetic Vertical Datum of 1929. the highest zone is defined at the top of the dam. Above this "top of dam" zone, no operational limits are imposed on the releases from the reservoir. Because of the implementation of physical limits on releases from the reservoir by scripted rules in the Chain of Lakes model, the definition of the flood control zone is necessary, although setting the elevation is somewhat arbitrary. Setting the flood control zone elevation is a modeling decision rather than an operational decision. Because of the nature of the reservoir model, the zone elevation has to be high enough so that it will not be encountered during a simulation, but low enough so that the scaling of the plots of the simulation results is useful.

The flood control zone elevation is set to $742.0 \mathrm{ft}$. The peak of record at Fox Lake near Lake Villa, occurring on April 6, 1960, is $741.18 \mathrm{ft}$. A more recent peak of $740.91 \mathrm{ft}$ occurred on April 22, 2013. Operations above the flood control zone are not affected by scripted or release function rules. This means that the physical limits scripted rules will not affect operations, and this will have a detrimental effect on the model; however, given the storage and elevation relation of this reservoir, the elevation of the flood control zone is above anything that is expected to be encountered during a model simulation.

\section{Standard Operations}

The standard operation zone is the zone above the guide curve that has release restrictions set to prevent downstream flooding. The zone is set to $738.45 \mathrm{ft}$. According to the operation manual for the dam at McHenry (Illinois Department of Natural Resources, 2012), the gates are set fully open to pass the flood flows at water-surface elevations above $738.45 \mathrm{ft}$. In the standard operation zone below $738.45 \mathrm{ft}$, a decision tree is used to set flows that minimize flooding both upstream in the lakes and downstream on the river. Pool elevations within this zone are above the target elevation for the reservoir, but the risk of flooding within the Chain of Lakes is low within this zone.

\section{Seasonal Pool}

The seasonal pool zone definition is the guide curve. The guide curve serves as the target pool elevation for the 
operation of the reservoir. From May 1 to November 1, the target elevation is $737.2 \mathrm{ft}$. The elevation during this period is known as the summer pool. From December 1 to April 1, the target elevation is $735.5 \mathrm{ft}$. The elevation during this period is known as the winter pool. The transition from winter pool to summer pool occurs between April 1 and May 1, and the target elevation varies linearly from $735.5 \mathrm{ft}$ to $737.2 \mathrm{ft}$. The transition from summer pool to winter pool occurs between November 1 and December 1. This period is known as winter drawdown. During winter drawdown, the target elevation varies linearly from $737.2 \mathrm{ft}$ to $735.5 \mathrm{ft}$.

\section{Inactive}

No operation rules are applied within the inactive zone. The inactive zone elevation ( $735 \mathrm{ft}$ ) is the top elevation of dead storage. Below this elevation, no releases from the reservoir are made.

\section{Operation Rules}

Operation rules exist because of operational constraints. The rules implement maximum flow to prevent downstream flooding, a minimum flow for stream protection, and a specified flow to allow maximum flow through the McHenry control structure. Operation rules are implemented in the same manner as the physical limit rules described in the "Scripted Physical Limit Rules" section. Operation rules are described in table 9.

\section{Operation Sets}

An operation set is a plan on which release decisions can be made. Operation sets consist of zones and rules assigned to those zones. The zones described in the "Operation Zones" section are defined in each operation set. The operation sets within the Chain of Lakes reservoir model are

- Physical limits,

- Standard operations,

- Ice jam operations, and

- Specify maximum flow.

Table 10 gives a summary of the zones and rules that are implemented in each operation set.

\section{Physical Limits}

In the physical limits operation set, the rules described in the "Scripted Physical Limit Rules" section are assigned to each zone except the inactive zone. No operation rules exist in this operation set. The physical limits operation set is implemented to allow for a simulation without effects of operation rules.

\section{Standard Operations}

The purpose of the standard operations set is to provide a plan for release decision during normal operating procedures. In this operation set, the rules described in the "Scripted Physical Limit Rules" section are assigned to each zone except the inactive zone. In addition, operation rules are assigned to the flood control and standard operations zones according to the flow chart in figure 22 in the operation manual for the dam at McHenry (Illinois Department of Natural Resources, 2012). The minimum flow for stream protection applies to the standard operations and seasonal pool zones.

Table 9. Operation rules in the Chain of Lakes Hydrologic Engineering Center-Reservoir System Simulation (HEC-ResSim) model. The rules as they are named in the HEC-ResSim appear under the "Rule name" column. Pool elevation is referenced to the National Geodetic Vertical Datum of 1929.

[Max, maximum; Q, flow; ft³/s, cubic feet per second; Spec, specify; ft, feet; SL, sluice gate; HCG, hinged-crest gate]

\begin{tabular}{ll}
\hline \multicolumn{1}{c}{ Rule name } & \multicolumn{1}{c}{ Description } \\
\hline Max Q 3000 & Maximum discharge of $3,000 \mathrm{ft}^{3} / \mathrm{s}$ implemented during standard operations \\
Max Q ice jam & Maximum discharge of $1,100 \mathrm{ft}^{3} / \mathrm{s}$ implemented during ice jam operations \\
Low Q protection & Minimum release for low flow protection ${ }^{1}$ \\
Spec 1800 & Specify a discharge of $1,800 \mathrm{ft}^{3} / \mathrm{s}$ \\
Spec 2550 & Specify a discharge of $2,550 \mathrm{ft}^{3} / \mathrm{s}$ \\
Spec 3000 & Specify a discharge of $3,000 \mathrm{ft}^{3} / \mathrm{s}$ \\
Spec Q from 736.6 to 737.2 & Specify a linearly increasing discharge from $1,800 \mathrm{ft}^{3} / \mathrm{s}$ to $3,000 \mathrm{ft}^{3} / \mathrm{s}$ between a pool elevation of $736.6 \mathrm{ft}$ \\
& and $737.2 \mathrm{ft}$ \\
Spec max SL capacity & Specify maximum discharge capacity with sluice gates fully opened \\
Spec max SL HCG capacity & Specify maximum discharge capacity with sluice and hinged-crest gates fully opened \\
\hline
\end{tabular}

${ }^{1}$ See page 48 of Illinois Department of Natural Resources, 2012, Operation of the Stratton and Algonquin Dams Fox River. 
Table 10. Summary of operation zones and rules applied in each operation set.

[Max, maximum; Q, flow; Min, minimum; BCW, broad-crested weir; HCG, hinged-crest gate; SL, sluice gate; Spec, specify]

\begin{tabular}{|c|c|c|c|c|c|c|c|c|c|c|c|c|c|}
\hline Operation set & Zone & 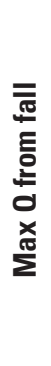 & 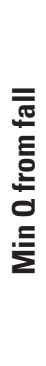 & 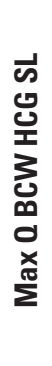 & 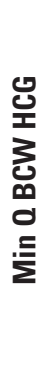 & 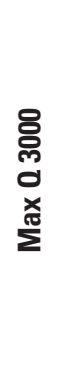 & 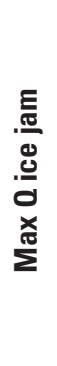 & 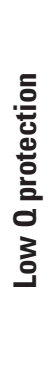 & 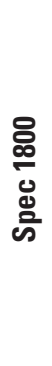 & 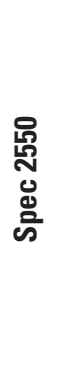 & $\begin{array}{l}\text { ర్ల } \\
\text { ப్ } \\
\text { के }\end{array}$ & 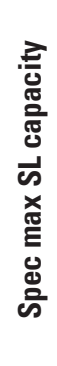 & 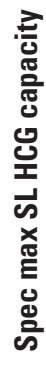 \\
\hline \multirow{4}{*}{ 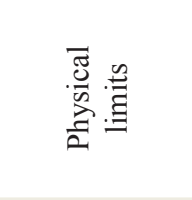 } & Flood control & $\bullet$ & - & $\bullet$ & $\bullet$ & & & & & & & & \\
\hline & Standard operations & - & • & $\bullet$ & • & & & & & & & & \\
\hline & Seasonal pool & • & • & - & • & & & & & & & & \\
\hline & Inactive & & & & & & & & & & & & \\
\hline \multirow{4}{*}{ 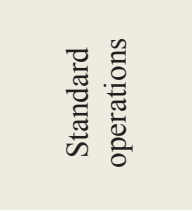 } & Flood control & • & - & - & - & & & & & & & $\bullet$ & • \\
\hline & Standard operations & - & • & - & - & $\bullet$ & & $\bullet$ & $\bullet$ & $\bullet$ & $\bullet$ & & $\bullet$ \\
\hline & Seasonal pool & • & - & - & $\bullet$ & & & $\bullet$ & & & & & \\
\hline & Inactive & & & & & & & & & & & & \\
\hline \multirow{4}{*}{ 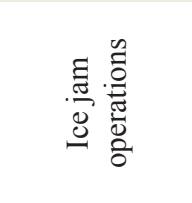 } & Flood control & • & • & • & • & & & & & & & & \\
\hline & Standard operations & $\bullet$ & - & $\bullet$ & $\bullet$ & & $\bullet$ & $\bullet$ & & & & & \\
\hline & Seasonal pool & - & - & - & • & & $\bullet$ & $\bullet$ & & & & & \\
\hline & Inactive & & & & & & & & & & & & \\
\hline \multirow{4}{*}{ 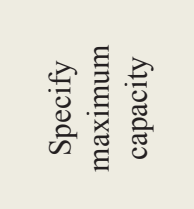 } & Flood control & - & - & & • & & & & & & & & • \\
\hline & Standard operations & - & - & & • & & & & & & & & - \\
\hline & Seasonal pool & - & - & & - & & & & & & & & - \\
\hline & Inactive & & & & & & & & & & & & \\
\hline
\end{tabular}

\section{Ice Jam Operations}

The ice jam operations set defines a plan for releases made during an ice jam downstream from the McHenry control structure. The ice jam operations set consists of all the physical limits rules described in the "Scripted Physical Limit Rules" section assigned to each zone except the inactive zone. The ice jam operations flow of $1,100 \mathrm{ft}^{3} / \mathrm{s}$ is applied to the standard operations and seasonal pool zones. The minimum flow for stream protection is also applied to the standard operations and seasonal pool zones.

\section{Specify Maximum Flow}

The specify maximum flow operation set is an operational plan to release as much from the reservoir as physically possible. The operation set applies the maximum flow because of maximum fall and minimum uncontrolled flow rules to all zones except inactive; in addition, the flow that is calculated with all gates at the fully opened position is specified.

\section{Model Evaluation}

In order to evaluate the performance of the reservoir model, a predicted inflow time series from the NWS operational forecasting system was used as the input time series for the reservoir model. The CHPS uses several of the traditional models and techniques used within the NWS (Roe and others, 2009). Operationally, these models simulate at a 6-hour time step and use basin-specific mean areal precipitation and mean areal temperature 6-hour data as the key driving inputs.

The time series begins October 1, 2003, and ends October 1, 2013. Simulated reservoir releases were calculated using the standard operations set. Although historical gate operations at the control structure are available, HEC-ResSim does not allow for the specification of reservoir releases by setting the gate openings. Additionally, there are no gages that provide observed outflows from the reservoir, so reservoir releases cannot be specified. Evaluation of the model was restricted to time periods where it was assumed that physical 
limitations within the channel were the primary factor in flow restriction, and gate operations had little effect on the observed reservoir pool elevation. To reduce uncertainty on whether physical limitations were the primary factor in release limitations, periods with peak elevations above the standard operations zone elevation of $738.45 \mathrm{ft}$ were evaluated. Operationally, when the Chain of Lakes pool elevation is above this zone, the sluice and hinged-crest gates are set to the maximum opening (Illinois Department of Natural Resources, 2012), so that the releases are restricted to the physical limits of the system. Despite the elevation restriction, observed elevation time series at the low end of the elevation range may still be affected by the actual operations of the control structure at the reservoir outlet.

Using this method to choose events, nine periods during high pool elevation met these criteria. The peak elevations were graphically compared to the closest-in-time observed pool elevation peak. Figures 10-18 show the simulated and observed time series for each event that has a peak in table 11 . The simulated and observed peaks are tabulated in table 11 . The graphic comparison of the simulated elevation time series to the observed series gives a thorough evaluation of the usefulness of the model. The simulated and observed elevation time series are graphically compared in figures 10-18. The periods of poorest performance are shown in figures 15 and 18 , whereas the simulated time series in periods shown in figures $11,12,13,16$, and 17 match the observed time series very well.

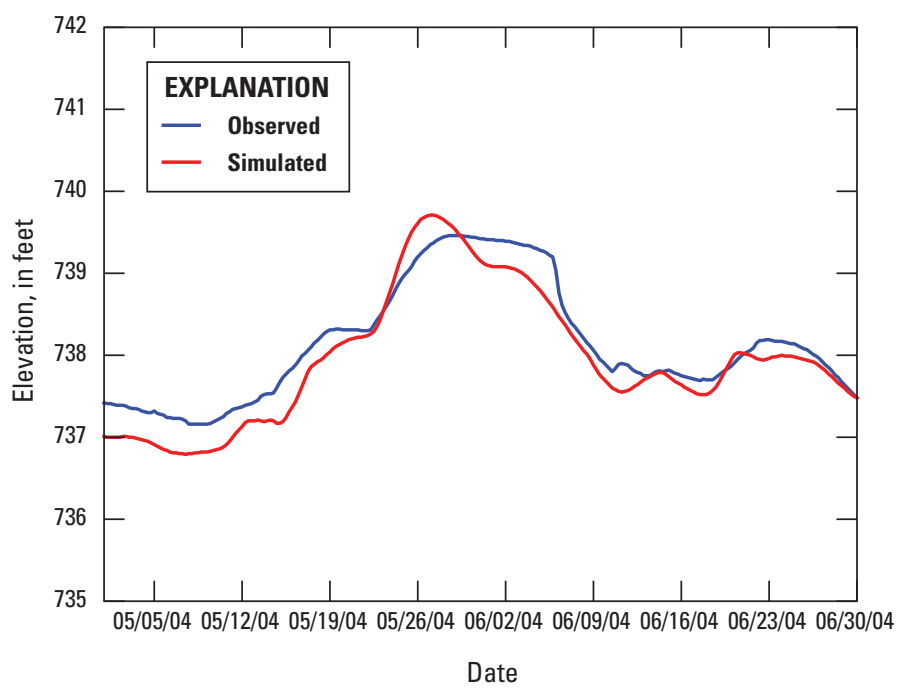

Figure 10. Simulated and observed elevation time series at Fox Lake near Lake Villa, Illinois (05547500), plotted for the event that has an observed peak pool elevation of $739.46 \mathrm{ft}$ that occurs on May 28,2004 , at 12:00 p.m. The simulated peak of $739.71 \mathrm{ft}$ occurs on May 27, 2004, at 12:00 a.m. Water-surface elevation is referenced to the National Geodetic Vertical Datum of 1929.
The mean difference in the simulated and observed peaks was $-0.03 \mathrm{ft}$, with a standard deviation of $0.19 \mathrm{ft}$ for the nine events where the peak elevation was above the standard operation zone of $738.45 \mathrm{ft}$ at the Fox Lake near Lake Villa, Ill. (05547500), streamgage. The minimum discrepancy in peak elevation occurs at an observed time on August 27, 2007, at 12:00 p.m., when the simulated elevation is $0.03 \mathrm{ft}$ lower than the observed elevation (fig. 11) and again at an observed time on August 3, 2010, at 12:00 p.m., when the simulated elevation is $0.03 \mathrm{ft}$ higher than the observed elevation (fig. 16). The minimum discrepancy in time of peak occurs on August 3, 2010, at an observed time of 12:00 p.m., when the simulated peak occurs at the same time as the observed peak (fig. 16). The greatest discrepancy in peak elevation occurs on June 23, 2009, at an observed time of 12:00 p.m., when the simulated elevation is $0.39 \mathrm{ft}$ lower than the observed elevation (fig. 15). The greatest discrepancy in time of peak occurs on July 1, 2013, at an observed time of 12:00 p.m., when the simulated peak occurs 42 hours before the observed peak (fig. 18).

The simulated peak elevations plotted against the observed peaks are shown in figure 19. Table 12 shows the Nash-Sutcliffe model efficiency coefficient for predicting the peak pool elevation. The calculated Nash-Sutcliffe model efficiency coefficient of 0.94 indicates that the model has high predictive capability. Although the coefficient provides a simple way to evaluate the model, the metric should not be overly emphasized. In the calculation of the coefficient, only

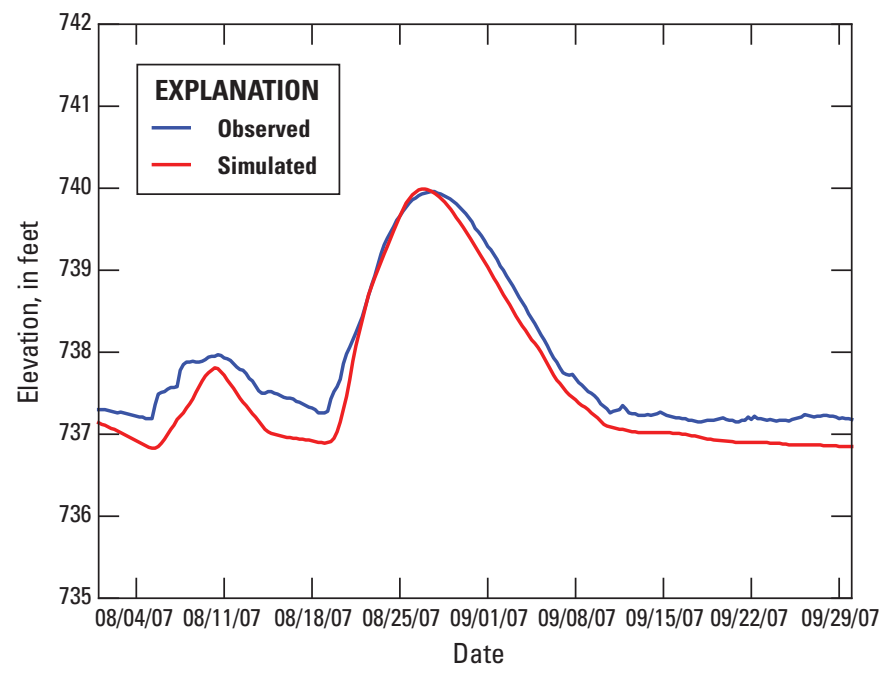

Figure 11. Simulated and observed elevation time series at Fox Lake near Lake Villa, Illinois (05547500), plotted for the event that has an observed peak pool elevation of $739.96 \mathrm{ft}$ that occurs on August 27, 2007, at 12:00 p.m. The simulated peak of $739.99 \mathrm{ft}$ occurs on August 26, 2007, at 6:00 p.m. Water-surface elevation is referenced to the National Geodetic Vertical Datum of 1929. 


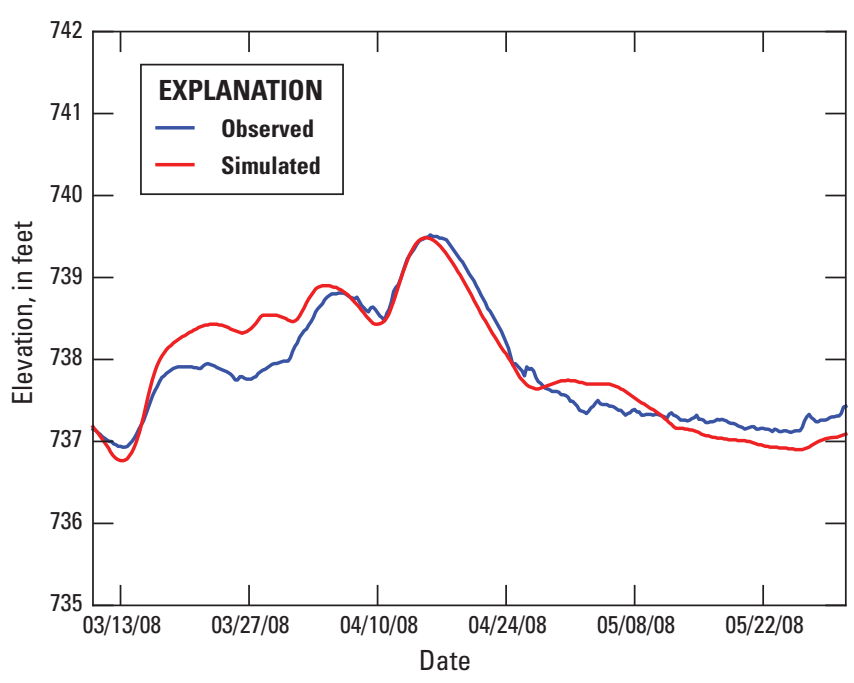

Figure 12. Simulated and observed elevation time series at Fox Lake near Lake Villa, Illinois (05547500), plotted for the event that has an observed peak pool elevation of $739.52 \mathrm{ft}$ that occurs on April 15, 2008, at 6:00 p.m. The simulated peak of $739.48 \mathrm{ft}$ occurs on April 15, 2008, at 12:00 a.m. Water-surface elevation is referenced to the National Geodetic Vertical Datum of 1929.

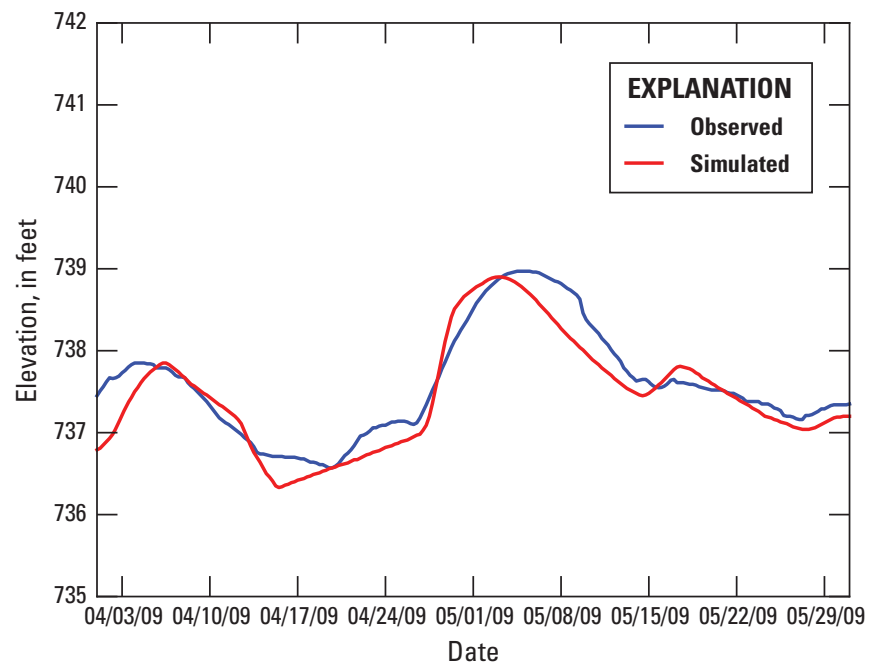

Figure 14. Simulated and observed elevation time series at Fox Lake near Lake Villa, Illinois (05547500), plotted for the event that has an observed peak pool elevation of $738.97 \mathrm{ft}$ that occurs on May 4, 2009, at 12:00 p.m. The simulated peak of $738.90 \mathrm{ft}$ occurs on May 3, 2009, at 12:00 a.m. Water-surface elevation is referenced to the National Geodetic Vertical Datum of 1929.

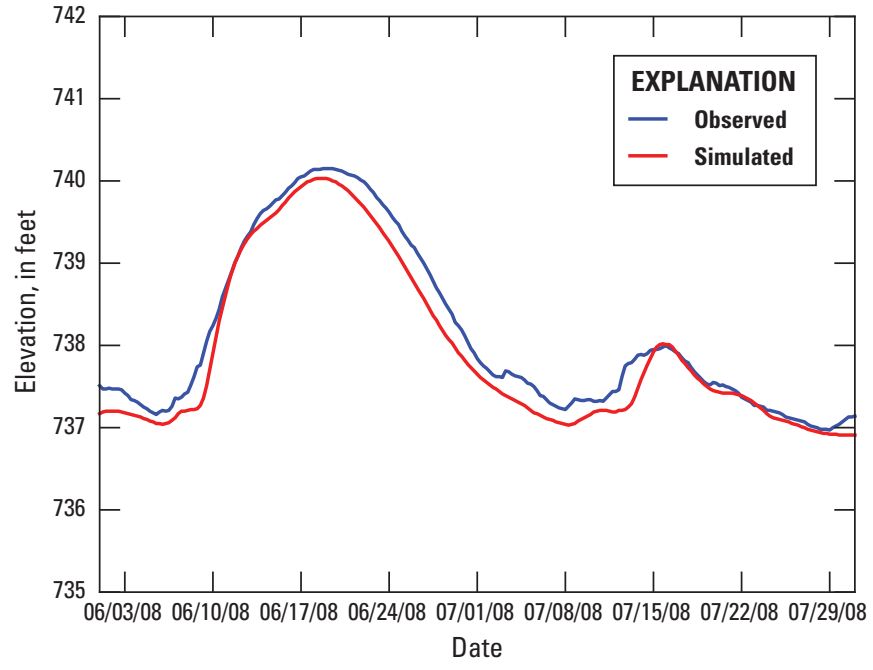

Figure 13. Simulated and observed elevation time series at Fox Lake near Lake Villa, Illinois (05547500), plotted for the event that has an observed peak pool elevation of $740.15 \mathrm{ft}$ that occurs on June 18,2008 , at 6:00 p.m. The simulated peak of $740.03 \mathrm{ft}$ occurs on June 18, 2008, at 6:00 a.m. Water-surface elevation is referenced to the National Geodetic Vertical Datum of 1929.

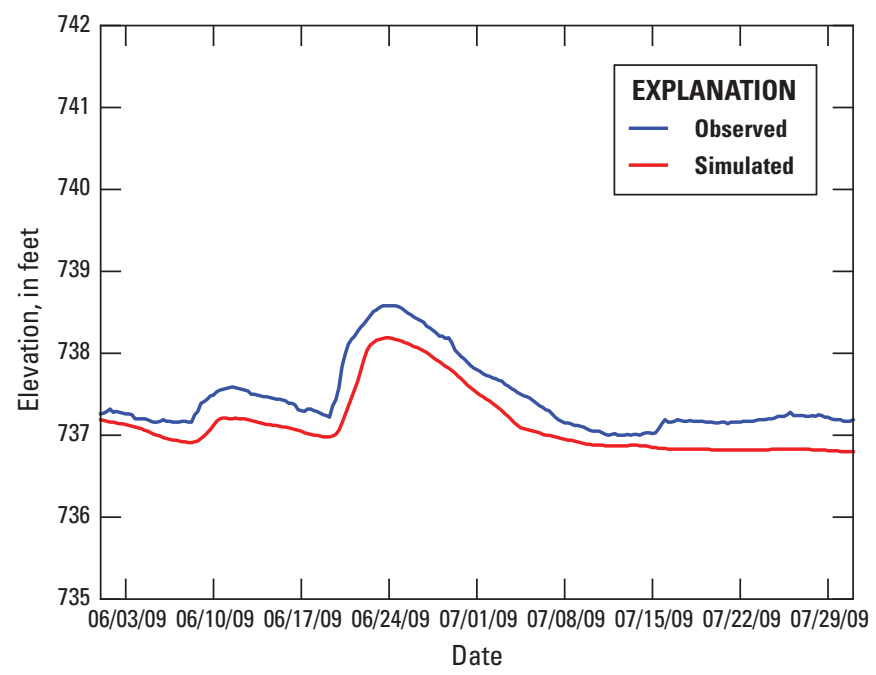

Figure 15. Simulated and observed elevation time series at Fox Lake near Lake Villa, Illinois (05547500), plotted for the event that has an observed peak pool elevation of $738.58 \mathrm{ft}$ that occurs on June 23, 2009, at 12:00 p.m. The simulated peak of $738.19 \mathrm{ft}$ occurs on June 23, 2009, at 6:00 p.m. Water-surface elevation is referenced to the National Geodetic Vertical Datum of 1929. 


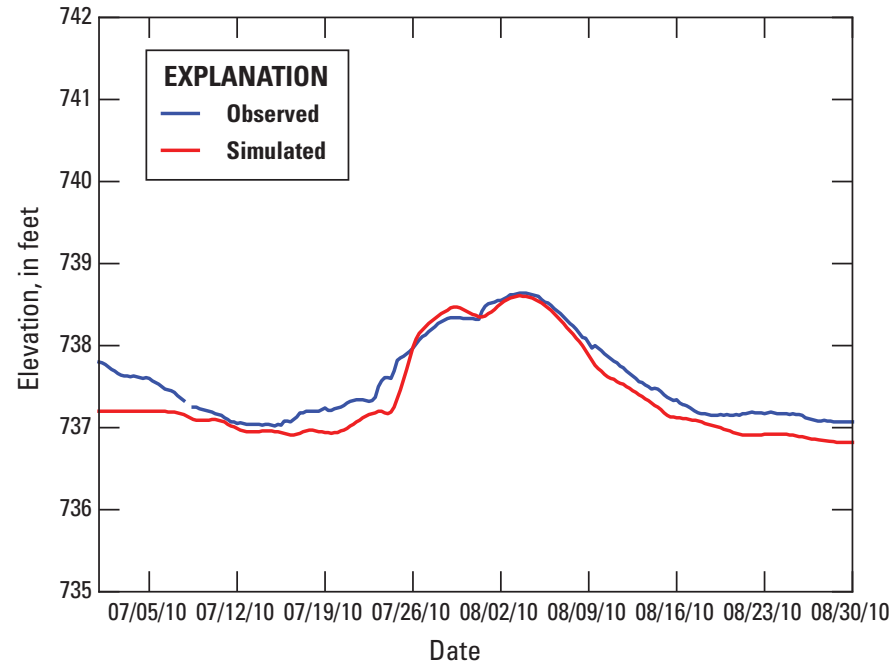

Figure 16. Simulated and observed elevation time series at Fox Lake near Lake Villa, Illinois (05547500), plotted for the event that has an observed peak pool elevation of $738.64 \mathrm{ft}$ that occurs on August 3, 2010, at 12:00 p.m. The simulated peak of $738.61 \mathrm{ft}$ occurs on August 3, 2010, at 12:00 p.m. Water-surface elevation is referenced to the National Geodetic Vertical Datum of 1929.

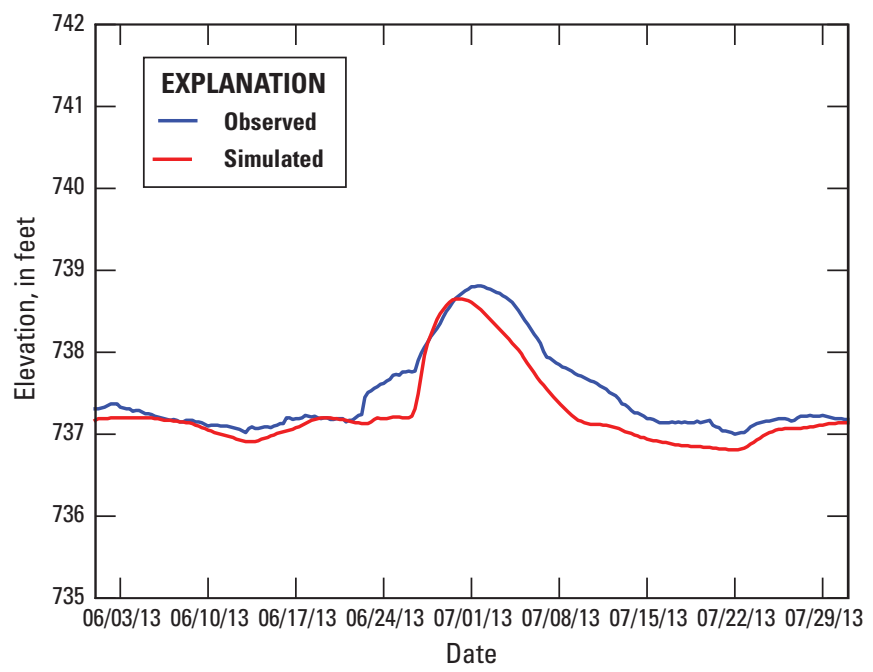

Figure 18. Simulated and observed elevation time series at Fox Lake near Lake Villa, Illinois (05547500), plotted for the event that has an observed peak pool elevation of $738.81 \mathrm{ft}$ that occurs on July 1, 2013, at 12:00 p.m. The simulated peak of $738.65 \mathrm{ft}$ occurs on June 29,2013 , at 6:00 p.m. Water-surface elevation is referenced to the National Geodetic Vertical Datum of 1929.

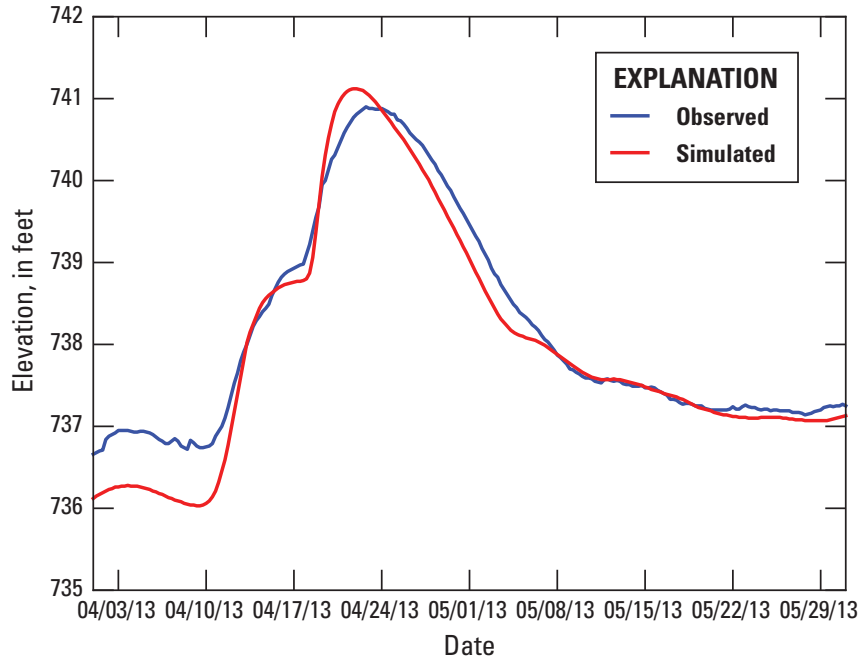

Figure 17. Simulated and observed elevation time series at Fox Lake near Lake Villa, Illinois (05547500), plotted for the event that has an observed peak pool elevation of $740.90 \mathrm{ft}$ that occurs on April 22, 2013, at 6:00 p.m. The simulated peak of $741.12 \mathrm{ft}$ occurs on April 21, 2013, at 6:00 p.m. Water-surface elevation is referenced to the National Geodetic Vertical Datum of 1929. 
Table 11. Comparison of selected peak elevations at Fox Lake near Lake Villa, Illinois (05547500), from a simulated time series beginning October 1, 2003, and ending October 1, 2013. Water-surface elevation is referenced to the National Geodetic Vertical Datum of 1929.

[ft, feet; hr, hour]

\begin{tabular}{|c|c|c|c|c|c|}
\hline \multicolumn{2}{|c|}{ Simulated } & \multicolumn{2}{|c|}{ Observed } & \multicolumn{2}{|c|}{ Simulated minus observed } \\
\hline Date and time & $\begin{array}{c}\text { Elevation } \\
\text { (ft) }\end{array}$ & Date and time & $\begin{array}{c}\text { Elevation } \\
\text { (ft) }\end{array}$ & $\begin{array}{c}\text { Time } \\
\text { (hr) }\end{array}$ & $\begin{array}{c}\text { Elevation } \\
\text { (ft) }\end{array}$ \\
\hline 05/27/2004 12:00 a.m. & 739.71 & 05/28/2004 12:00 p.m. & 739.46 & -36 & 0.25 \\
\hline 08/26/2007 6:00 p.m. & 739.99 & 08/27/2007 12:00 p.m. & 739.96 & -18 & 0.03 \\
\hline 04/15/2008 12:00 a.m. & 739.48 & 04/15/2008 6:00 p.m. & 739.52 & -18 & -0.04 \\
\hline 06/18/2008 6:00 a.m. & 740.03 & 06/18/2008 6:00 p.m. & 740.15 & -12 & -0.12 \\
\hline 05/03/2009 12:00 a.m. & 738.90 & 05/04/2009 12:00 p.m. & 738.97 & -36 & -0.07 \\
\hline 06/23/2009 6:00 p.m. & 738.19 & 06/23/2009 12:00 p.m. & 738.58 & 6 & -0.39 \\
\hline 08/03/2010 12:00 p.m. & 738.61 & 08/03/2010 12:00 p.m. & 738.64 & 0 & -0.03 \\
\hline 04/21/2013 6:00 p.m. & 741.12 & 04/22/2013 6:00 p.m. & 740.90 & -24 & 0.22 \\
\hline 06/29/2013 6:00 p.m. & 738.65 & 07/01/2013 12:00 p.m. & 738.81 & -42 & -0.16 \\
\hline
\end{tabular}

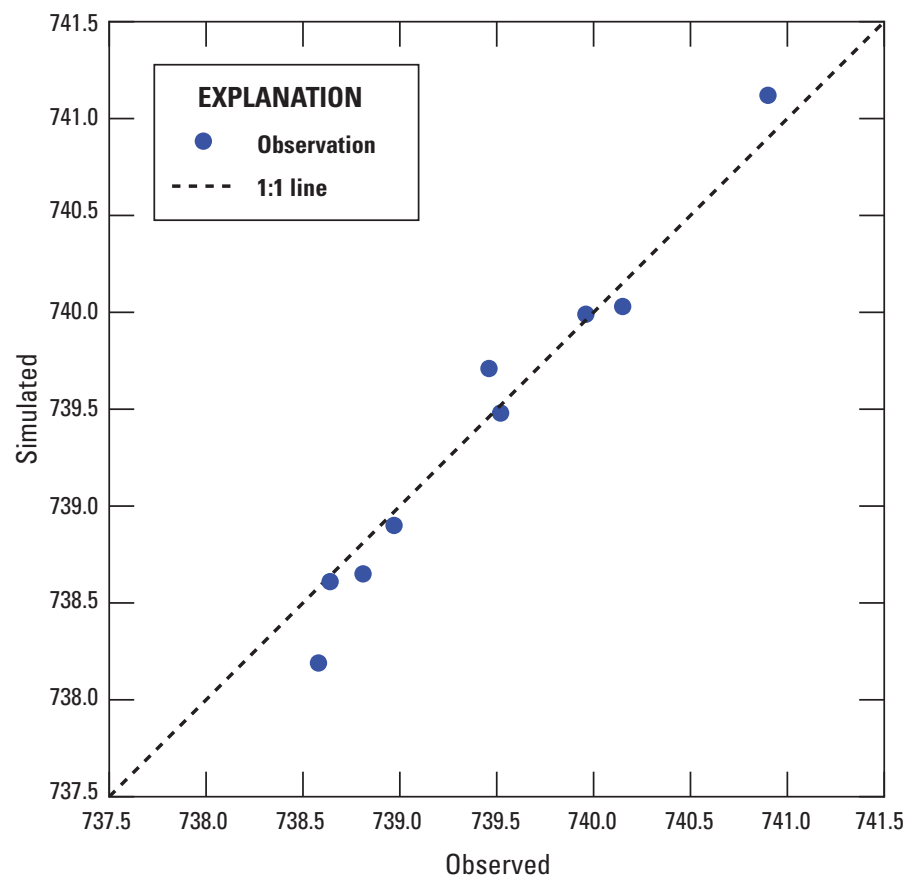

Figure 19. Simulated and observed peak elevations at Fox Lake near Lake Villa, Illinois (05547500). Water-surface elevation is referenced to the National Geodetic Vertical Datum of 1929.

Table 12. Nash-Sutcliffe model efficiency coefficient for the prediction of peak elevation at Fox Lake near Lake Villa, Illinois (05547500).

\begin{tabular}{cc}
\hline Variable & Nash-Sutcliffe efficiency \\
\hline Peak elevation at Fox Lake near Lake Villa, Ill. (05547500) & 0.94 \\
\hline
\end{tabular}


nine peak elevations were considered, and the rest of the time series were ignored. Because the model is not intended to predict only peak pool elevations, the Nash-Sutcliffe model efficiency coefficient, calculated using the peak elevations, is an incomplete measure of model performance. However, the combination of this statistic with the computed differences in peaks and the graphical comparison of time series provides an evaluation that leads to the conclusion that the model is performing adequately at high reservoir elevations.

\section{Summary}

During flood events, forecasts of flows entering and leaving the Chain of Lakes reservoir on the Fox River in northeastern Illinois are critical to the optimal operation of the dam, also known as Stratton Dam, at McHenry, Ill., to help minimize damages to property and loss of life. In 2014, the U.S. Geological Survey (USGS), the Illinois Department of Natural Resources, Office of Water Resources (IDNR-OWR), and the National Weather Service (NWS) began a cooperative study to develop a system to enable engineers and planners to prepare proactively for precipitation events in near real time in the upper Fox River watershed. The purpose of this report is to document the development and evaluation of the Chain of Lakes reservoir model developed in this study.

The Hydrologic Engineering Center-Reservoir System Simulation (HEC-ResSim) program was used as the primary tool for determining Chain of Lakes reservoir routing characteristics and the optimal operation of control structures at McHenry according to the reservoir operation guidelines in use. Reservoir operation guidelines described in the study are from the IDNR-OWR operation manual. The input and output of the reservoir model corresponded to basin outlet locations in the NWS Community Hydrologic Prediction System (CHPS). The storage-elevation curve for the reservoir model is from the IDNR control structure operations manual, and the release capacity of the control structures were based on the ratings described in a previous USGS report. Because of the complex relation between the dam headwater and reservoir pool elevations, the reservoir model uses a linear regression model that relates control structure headwater elevation to pool elevation in scripted rules for physical limits.

A linear regression model that describes the relation between the headwater gage height at Fox River near McHenry, Ill. (05549500), and the pool elevation at Fox Lake near Lake Villa, Ill. (05547500), was developed. A second linear regression model was developed for a relation between flow and the gage height at Fox River (tailwater) near McHenry, Ill. (05549501). Because the linear regression models were used to predict flow, gage height, and fall, a geometric mean functional relationship (GMFR) regression method, which considers error in all variables, was used. The linear regression models were developed using 17 USGS streamflow measurements along with gage height in the reservoir pool and the headwater and tailwater gage heights of the dam. For all variables of the linear regression models, the Nash-Sutcliffe model efficiency coefficients ranged from 0.90 to 0.98 .

A predicted inflow time series from CHPS was used as the input time series for the reservoir model in order to evaluate the performance of the reservoir model. From the results, nine simulated pool elevation peaks during period of high pool elevation were evaluated and graphically were compared to the closest-in-time observed pool elevation peak. The Nash-Sutcliffe model efficiency coefficient, calculated using the simulated and observed peaks, was 0.94 . Additionally, the simulated and observed time series during the periods surrounding the peaks were plotted and graphically compared. The model simulation results were satisfactory.

\section{References}

Draper, N.R., and Yang, Yonghong, 1997, Generalization of the geometric mean functional relationship: Computational Statistics and Data Analysis, v. 23, p. 355-372.

Helsel, D.R., and Hirsch, R.M., 2002, Statistical methods in water resources: U.S. Geological Survey Techniques of Water-Resources Investigations, book 4, chap. A3, 522 p.

Illinois Department of Natural Resources, 2012, Operation of the Stratton and Algonquin Dams Fox River, accessed February 2016, at https://www.dnr.illinois.gov/WaterResources/ Documents/StrattonAlgonquinDams.pdf.

Kennedy, E.J., 1984, Discharge ratings at gaging stations: U.S. Geological Survey Techniques of Water-Resources Investigations, book 3, chap. A10, 59 p. (Also available at http://pubs.usgs.gov/twri/twri3-a10/.)

Nash, J.E., and Sutcliffe, J.V., 1970, River flow forecasting through conceptual models, Part 1-A discussion of principles: Journal of Hydrology, v. 10, p. 282-290.

Roe, Jon, Restrepo, Pedro, Halquist, John, Hartman, Robert, Horwood, Ronald, Olsen, Billy, Opitz, Harold, Shedd, Robert, and Wells, Edwin, 2009, NOAA's community hydrologic prediction system, accessed August 2016, at http://amazon.nws.noaa.gov/articles/HRL_Pubs PDF_May12_2009/New_Scans_February_2010/7 E Roe_12_28_09_Community_Hydro_Pred.pdf.

Schrader, D.L., and Holmes, R.R., Jr., 2000, Suspendedsediment budget, flow distribution, and lake circulation for the Fox Chain of Lakes in Lake and McHenry Counties, Illinois, 1997-99: U.S. Geological Survey Water-Resources Investigations Report 2000-4115, 23 p.

Straub, T.D., Johnson, G.P., Hortness, J.E., and Parker, J.R., 2009, Control-structure ratings on the Fox River at McHenry and Algonquin, Illinois: U.S. Geological Survey Scientific Investigations Report 2009-5186, 61 p.

U.S. Army Corps of Engineers, 2013, HEC-ResSim Reservoir system simulation user's manual, version 3.1, $556 \mathrm{p}$. 

Prepared by the Science Publishing Network, Lafayette, Madison, and Pembroke Publishing Service Centers. 


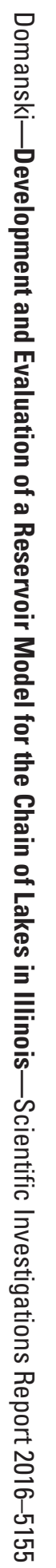

